\title{
Federal Reserve
}

\section{Residential Mortgage Lending from 2004 to 2015: Evidence from the Home Mortgage Disclosure Act Data}

\author{
Neil Bhutta and Daniel R. Ringo, of the Division of Research and Statistics, prepared this \\ article. Jimmy Kelliher provided research assistance.
}

This article provides an overview of residential mortgage lending in 2015 and discusses a number of changes in mortgage market activity over time based on data reported under the Home Mortgage Disclosure Act of 1975 (HMDA). HMDA requires most mortgage lending institutions with offices in metropolitan areas to disclose to the public detailed information about their home-lending activity each year. The HMDA data include the disposition of each application for mortgage credit; the type, purpose, and characteristics of each home mortgage that lenders originate or purchase during the calendar year; the census-tract designations of the properties related to those loans; loan pricing information; personal demographic and other information about loan applicants, including their race or ethnicity and income; and information about loan sales (see appendix A for a full list of items reported under HMDA). ${ }^{1}$

HMDA was enacted to help members of the public determine whether financial institutions are serving the housing needs of their local communities and treating borrowers and loan applicants fairly, provide information that could facilitate the efforts of public entities to distribute funds to local communities for the purpose of attracting private investment, and help households decide where they may want to deposit their savings. ${ }^{2}$ The data have proven to be valuable for research and are often used in public policy deliberations related to the mortgage market. ${ }^{3}$

Mortgage debt is by far the largest component of household debt in the United States, and mortgage transactions can have important implications for households' financial wellbeing. The HMDA data are the most comprehensive source of publicly available information on the U.S. mortgage market, providing unique details on how much mortgage credit

1 The 2015 HMDA data reflect property locations using the census-tract geographic boundaries created for the 2010 decennial census as well as recent updates to the list of metropolitan statistical areas (MSAs) published by the Office of Management and Budget. The first year for which the HMDA data use this most recent list of MSAs is 2014. For further information, see Federal Financial Institutions Examination Council (2013), "OMB Announcement—Revised Delineations of MSAs," press release, February 28, www.ffiec.gov/hmda/OMB_MSA.htm.

2 A brief history of HMDA is available at Federal Financial Institutions Examination Council, "History of HMDA," webpage, www.ffiec.gov/hmda/history2.htm.

3 On July 21, 2011, rulemaking responsibility for HMDA was transferred from the Federal Reserve Board to the newly established Consumer Financial Protection Bureau. The Federal Financial Institutions Examination Council (FFIEC; www.ffiec.gov) continues to be responsible for collecting the HMDA data from reporting institutions and facilitating public access to the information. In September of each year, the FFIEC releases to the public summary disclosure tables pertaining to lending activity from the previous calendar year for each reporting lender as well as aggregations of home-lending activity for each metropolitan statistical area and for the nation as a whole. The FFIEC also makes available to the public a data file containing virtually all of the reported information for each lending institution as well as a file that includes key demographic and housing-related data for each census tract drawn from census sources. 
gets extended each year, who obtains such credit, and which institutions provide such credit.

In 2015, house prices continued their upward trend evident since 2012, and mortgage interest rates remained low, although slightly above the historical lows reached in late 2012 and early 2013. Mortgage credit conditions continued to slowly ease, but credit remained more difficult to obtain for individuals with lower credit scores. Reports throughout the year from the Senior Loan Officer Opinion Survey on Bank Lending Practices indicate that several large banks relaxed their credit requirements, on net, for mortgages that were eligible for purchase by the government-sponsored enterprises (GSEs) or that met the Consumer Financial Protection Bureau's standards for qualified mortgages. ${ }^{4}$ Growth in new housing construction continued at a moderate pace. ${ }^{5}$

This article presents findings from the HMDA data describing mortgage market activity and lending patterns over time, including the incidence of higher-priced or nonprime lending and rates of denial on mortgage applications, across different demographic groups and lender types. ${ }^{6}$ Some of the key findings are as follows:

1. The number of mortgage originations in 2015 rose 22 percent, to 7.4 million from 6.1 million in 2014. For loans secured by one- to four-family properties, growth was strong in both home-purchase originations - which increased to 3.7 million from 3.2 million in 2014 - and refinance originations - which increased to 3.2 million from 2.4 million in 2014.

2. The nonconventional share (that is, loans with mortgage insurance from the Federal Housing Administration (FHA) or guarantees from the Department of Veterans Affairs (VA), the Farm Service Agency (FSA), or the Rural Housing Service (RHS)) of first-lien home-purchase loans for one- to four-family, owner-occupied, site-built (that is, not manufactured) properties stood at about 39 percent in 2015, up from 36 percent in 2014 and down from a peak of 54 percent in 2009. The rise in the nonconventional share in 2015 reflects an increase in FHA lending after the FHA significantly reduced the annual mortgage insurance premium (MIP) it charges borrowers.

3. Black and Hispanic white borrowers increased their share of home-purchase loans for one- to four-family, owner-occupied, site-built properties in 2015. The HMDA data indicate that 5.5 percent of such loans went to black borrowers, up from 5.2 percent in 2014, while 8.3 percent went to Hispanic white borrowers, up from 7.9 percent in 2014, building on gains both groups experienced from 2013 to 2014. The share of home-purchase loans to low- or moderate-income (LMI) borrowers increased slightly to 28 percent in 2015 from 27 percent in 2014.

4. In 2015, only about 3 percent of conventional home-purchase loans and 2 percent of conventional refinance loans were higher priced. However, small banks and credit unions were much more likely to originate conventional higher-priced loans than large banks and mortgage companies and thus accounted for a highly disproportionate share of conventional higher-priced loans in 2015. For example, while small banks and credit unions accounted for about 18 percent of conventional home-purchase loans, they originated about 47 percent of higher-priced conventional home-purchase loans.

4 The survey is available on the Board's website at www.federalreserve.gov/boarddocs/snloansurvey.

5 For more information on credit and economic conditions during 2015, see Board of Governors of the Federal Reserve System (2016), Monetary Policy Report (Washington: Board of Governors, February 10), www.federalreserve.gov/monetarypolicy/mpr_default.htm.

6 Some lenders file amended HMDA reports, which are not reflected in the initial public data release. The data used to prepare this article are drawn from the initial public release for 2015 and from amended HMDA data for years prior to that. Consequently, numbers in this article for the years 2014 and earlier may differ somewhat from numbers calculated from the public release files. 
5. The share of mortgages originated by nondepository, independent mortgage companies has increased sharply in recent years. In 2015, this group of lenders accounted for 50 percent of first-lien owneroccupant home-purchase loans, up 3 percentage points over 2014. Independent mortgage companies also originated 48 percent of first-lien owneroccupant refinance loans, an increase of 6 percentage points from 2014. Both levels are higher than at any point since at least 1995.

\section{Mortgage Applications and Originations}

In 2015, 6,913 institutions reported data on nearly 12.1 million home mortgage applications (including about 2 million applications that were closed by the lender for incompleteness or were withdrawn by the applicant before a decision was made) that resulted in about 7.4 million originations. The number of originations in 2015 was up from 6 million originations in 2014 (table 1).

Refinance mortgages for one- to four-family properties increased by 860,000 , or 36 percent, from 2014 to 2015 following declines in the previous two years. One- to four-family home-purchase originations grew by almost 421,000, or 13 percent, from 2014. Most one- to four-family home-purchase loans are first liens for owner-occupied properties. In the past four years, such loans have grown over 50 percent, from less than 2.1 million in 2011 to 3.2 million in 2015. However, the volume of such home-purchase originations still stands well below its peak in 2005 and is near levels observed in the mid-1990s (figure 1). ${ }^{7}$ The number of first-lien home-purchase loans for non-owneroccupied properties - that is, purchases of rental properties, vacation properties, and second homes - increased from 378,000 in 2014 to 403,000 in 2015.

7 The HMDA data prior to 2004 did not provide lien status for loans, and thus the number of loans prior to 2004 includes both first- and junior-lien loans. That said, including junior-lien home-purchase loans in 2015 does not change the conclusion that home-purchase lending in 2015 was similar to that in the mid-1990s, particularly 1994.
Figure 1. Number of home-purchase and refinance

Disclosure Act, 1994-2015

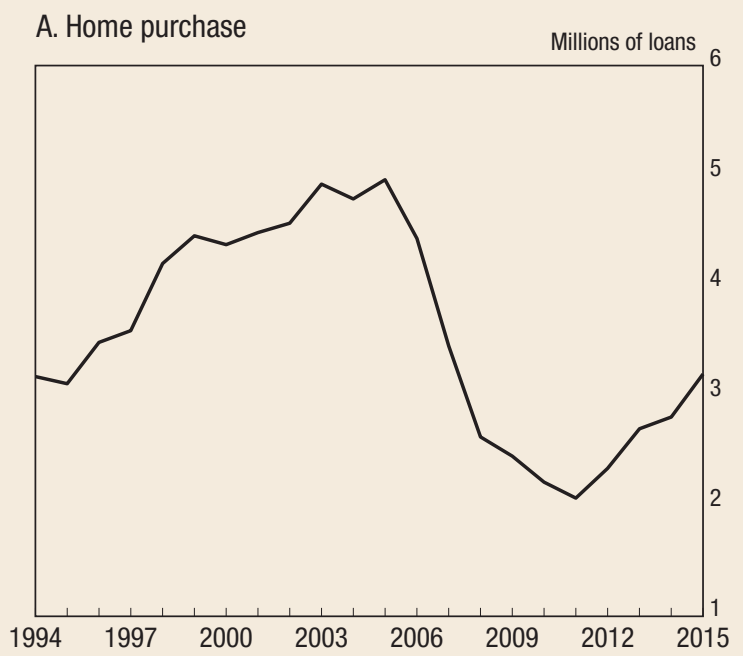

\section{B. Refinance}

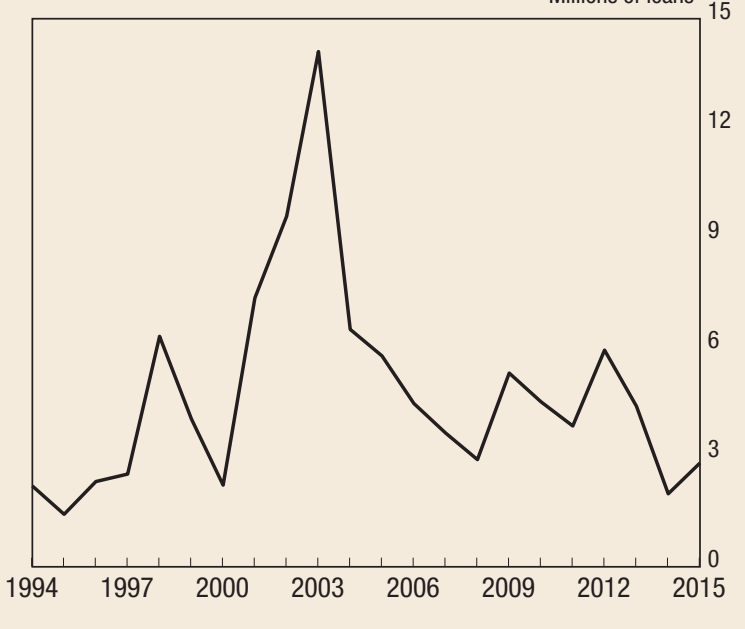

Note: The data are annual. Mortgage originations for one- to four-family owneroccupied properties, with junior-lien loans excluded in 2004 and later. mortgage originations reported under the Home Mortgage 


\section{Table 1. Applications and originations, 2004-15}

Numbers of loans, in thousands, except as noted

\begin{tabular}{|c|c|c|c|c|c|c|c|c|c|c|c|c|}
\hline $\begin{array}{l}\text { Characteristic of loan } \\
\text { and of property }\end{array}$ & 2004 & 2005 & 2006 & 2007 & 2008 & 2009 & 2010 & 2011 & 2012 & 2013 & 2014 & 2015 \\
\hline \multicolumn{13}{|l|}{ 1-4 Family } \\
\hline \multicolumn{13}{|l|}{ Home purchase } \\
\hline Applications & 9,804 & 11,685 & 10,929 & 7,609 & 5,060 & 4,217 & 3,848 & 3,650 & 4,023 & 4,586 & 4,670 & 5,181 \\
\hline Originations & 6,437 & 7,391 & 6,740 & 4,663 & 3,139 & 2,793 & 2,547 & 2,430 & 2,742 & 3,139 & 3,241 & 3,662 \\
\hline First lien, owner occupied & 4,789 & 4,964 & 4,429 & 3,454 & 2,628 & 2,455 & 2,218 & 2,073 & 2,343 & 2,703 & 2,809 & 3,200 \\
\hline Site-built, conventional & 4,107 & 4,425 & 3,912 & 2,937 & 1,581 & 1,089 & 1,005 & 999 & 1,251 & 1,630 & 1,738 & 1,894 \\
\hline Site-built, nonconventional & 553 & 411 & 386 & 394 & 951 & 1,302 & 1,151 & 1,019 & 1,033 & 1,007 & 1,003 & 1,230 \\
\hline FHA share (percent) & 74.6 & 68.6 & 66.0 & 65.8 & 78.9 & 77.0 & 77.4 & 70.9 & 68.0 & $62.8-r-v-v-1$ & 58.3 & 64.6 \\
\hline VA share (percent) & 21.6 & 26.7 & 29.0 & 27.1 & 15.2 & 13.9 & 15.2 & 18.2 & 19.9 & 24.2 & 28.3 & 26.1 \\
\hline FSA/RHS share (percent) & 3.9 & 4.7 & 5.0 & 7.1 & 5.9 & 9.0 & 7.4 & 10.9 & 12.0 & 13.1 & 13.4 & 9.4 \\
\hline Manufactured, conventional & 106 & 100 & 101 & 95 & 68 & 43 & 44 & 40 & 44 & 51 & 51 & 56 \\
\hline Manufactured, nonconventional & 24 & 27 & 30 & 29 & 28 & 21 & 17 & 15 & 14 & 14 & 16 & 20 \\
\hline First lien, non-owner occupied & 857 & 1,053 & 880 & 607 & 412 & 292 & 285 & 314 & 355 & 388 & 378 & 403 \\
\hline Junior lien, owner occupied & 738 & 1,224 & 1,269 & 552 & 93 & 44 & 42 & 41 & 43 & 46 & 53 & 58 \\
\hline Junior lien, non-owner occupied & 53 & 150 & 162 & 50 & 6 & 2 & 2 & 1 & 1 & 1 & 2 & 2 \\
\hline \multicolumn{13}{|l|}{ Refinance } \\
\hline Applications & 16,085 & 15,907 & 14,046 & 11,566 & 7,805 & 9,983 & 8,433 & 7,422 & 10,526 & 8,564 & 4,527 & 5,940 \\
\hline Originations & 7,591 & 7,107 & 6,091 & 4,818 & 3,491 & 5,772 & 4,969 & 4,330 & 6,668 & 5,141 & 2,368 & 3,228 \\
\hline First lien, owner occupied & 6,497 & 5,770 & 4,469 & 3,659 & 2,934 & 5,301 & 4,516 & 3,856 & 5,930 & 4,393 & 1,999 & 2,841 \\
\hline Site-built, conventional & 6,115 & 5,541 & 4,287 & 3,407 & 2,363 & 4,264 & 3,835 & 3,315 & 4,971 & 3,634 & 1,607 & 2,152 \\
\hline Site-built, nonconventional & 297 & 151 & 110 & 180 & 506 & 979 & 646 & 508 & 917 & 715 & 362 & 658 \\
\hline FHA share (percent) & 68.3 & 77.3 & 87.5 & 91.5 & 92.2 & 83.7 & 79.3 & 63.2 & 61.2 & 61.2 & 47.6 & 59.5 \\
\hline VA share (percent) & 31.4 & 22.4 & 12.3 & 8.3 & 7.6 & 15.9 & 20.3 & 35.9 & 37.8 & 37.6 & 51.9 & 40.3 \\
\hline FSA/RHS share (percent) & .2 & .3 & .2 & .1 & .2 & .4 & .4 & .9 & 9 & 1.2 & .5 & .3 \\
\hline Manufactured, conventional & 77 & 70 & 60 & 56 & 42 & 36 & 25 & 25 & 31 & 32 & 22 & 21 \\
\hline Manufactured, nonconventional & 7 & 8 & 12 & 16 & 22 & 22 & 10 & 9 & 11 & 12 & 8 & 10 \\
\hline First lien, non-owner occupied & 618 & 582 & 547 & 474 & 330 & 350 & 359 & 394 & 660 & 673 & 309 & 328 \\
\hline Junior lien, owner occupied & 464 & 729 & 1,036 & 661 & 219 & 115 & 88 & 74 & 73 & 70 & 56 & 55 \\
\hline Junior lien, non-owner occupied & 13 & 25 & 39 & 23 & 9 & 7 & 6 & 5 & 5 & 5 & 4 & 4 \\
\hline \multicolumn{13}{|l|}{ Home improvement } \\
\hline Applications & 2,200 & 2,544 & 2,481 & 2,218 & 1,413 & 832 & 670 & 675 & 779 & 833 & 842 & 921 \\
\hline Originations & 964 & 1,096 & 1,140 & 958 & 573 & 390 & 341 & 335 & 382 & 425 & 409 & 474 \\
\hline \multicolumn{13}{|l|}{ Multifamily ${ }^{1}$} \\
\hline Applications & 61 & 58 & 52 & 54 & 43 & 26 & 26 & 35 & 47 & 51 & 46 & 52 \\
\hline Originations & 48 & 45 & 40 & 41 & 31 & 19 & 19 & 27 & 37 & 40 & 35 & 41 \\
\hline Total applications & 28,151 & 30,193 & 27,508 & 21,448 & 14,320 & 15,057 & 12,977 & 11,782 & 15,375 & 14,034 & 10,085 & 12,094 \\
\hline Total originations & 15,040 & 15,638 & 14,011 & 10,480 & 7,234 & 8,974 & 7,876 & 7,122 & 9,828 & 8,744 & 6,054 & 7,404 \\
\hline \multicolumn{13}{|l|}{ Memo } \\
\hline Purchased loans & 5,142 & 5,868 & 6,236 & 4,821 & 2,935 & 4,301 & 3,229 & 2,939 & 3,163 & 2,788 & 1,802 & 2,102 \\
\hline Requests for preapproval ${ }^{2}$ & 1,068 & 1,260 & 1,175 & 1,065 & 735 & 559 & 445 & 429 & 474 & 474 & 497 & 531 \\
\hline $\begin{array}{l}\text { Requests for preapproval that } \\
\text { were approved but not acted on }\end{array}$ & 167 & 166 & 189 & 197 & 99 & 61 & 53 & 55 & 64 & 69 & 64 & 63 \\
\hline $\begin{array}{l}\text { Requests for preapproval } \\
\text { that were denied }\end{array}$ & 171 & 231 & 222 & 235 & 177 & 155 & 117 & 130 & 149 & 123 & 127 & 114 \\
\hline
\end{tabular}

Note: Components may not sum to totals because of rounding. Applications include those withdrawn and those closed for incompleteness. FHA is Federal Housing Administration; VA is U.S. Department of Veterans Affairs; FSA is Farm Service Agency; RHS is Rural Housing Service.

1 A multifamily property consists of five or more units.

2 Consists of all requests for preapproval. Preapprovals are not related to a specific property and thus are distinct from applications.

Source: Here and in subsequent tables and figures, except as noted, Federal Financial Institutions Examination Council, data reported under the Home Mortgage Disclosure Act (www.ffiec.gov/hmda). 
In table 1, the volume of first-lien lending for owner-occupied properties is further disaggregated by loan and property type. (Versions of table 1 containing loan counts and dollar values by month are available in the Excel file posted online with this article.) In addition to lien and occupancy status, the HMDA data provide details on the type of property securing the loan (sitebuilt or manufactured home) and on the type of loan (conventional or not). ${ }^{8}$ As noted earlier, nonconventional lending involves loans with mortgage insurance or other guarantees from federal government agencies, including the FHA, the VA, the RHS, and the FSA. Conventional lending encompasses all other loans, including those sold to the GSEs Fannie Mae and Freddie Mac.

Nonconventional loans are more common for home purchases than for refinancings and usually involve high loan-to-value (LTV) ratiosthat is, the borrowers provide relatively small down payments. For site-built properties,

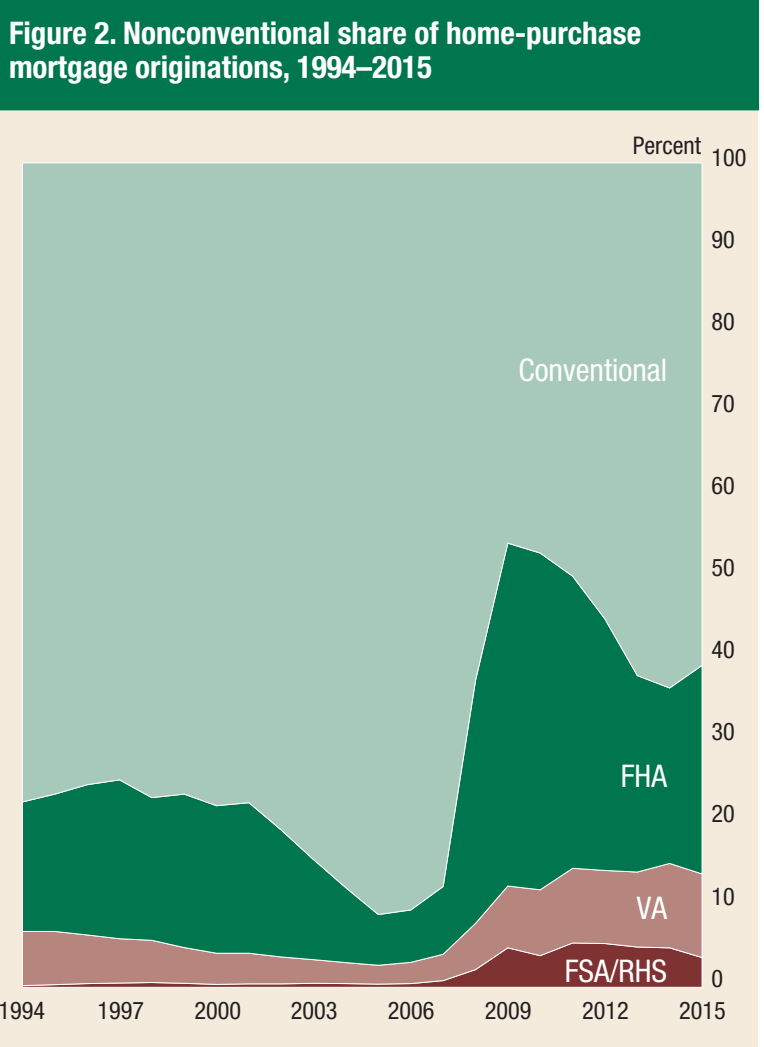

Note: The data are annual. Home-purchase mortgage originations for one- to four-family owner-occupied properties, with junior-lien loans excluded in 2004 and later. Nonconventional loans are those insured by the Federal Housing Administration (FHA) or backed by guarantees from the U.S. Department of Veterans Affairs (VA), the Farm Service Agency (FSA), or the Rural Housing Service (RHS). nonconventional home-purchase loans increased nearly 23 percent in 2015 , while conventional loans rose about 9 percent. The nonconventional share of first-lien home-purchase loans for one- to four-family, owner-occupied, site-built properties stood at about 39 percent in 2015 , up slightly from 36 percent in 2014 but down significantly from its peak of 54 percent in 2009 in the wake of the financial crisis (figure 2). ${ }^{9}$

Figure 2 shows that the marked decline in the nonconventional share since 2009 reflects a decrease in the FHA share of loans, while the VA and FSA/RHS shares have been steadier. One factor that may help explain the fluctuations in the FHA share concerns changes in the upfront and annual MIPs that the FHA charges borrowers. For example, between October 2010 and April 2013, the annual MIP for a typical home-purchase loan more than

8 Manufactured-home lending differs from lending on site-built homes, in part because most of the homes are sold without land and are treated as chattel-secured lending, which typically carries higher interest rates and shorter terms to maturity than those on loans to purchase site-built homes (for pricing information on manufactured home loans, see table 8). This article focuses almost entirely on site-built mortgage originations, which constitute the vast majority of originations (as shown in table 1). That said, it is important to keep in mind that, because manufactured homes typically are less expensive than site-built homes, they provide a low-cost housing option for households with more moderate incomes.

9 For a more detailed discussion of the post-crisis rise in nonconventional lending, see Robert B. Avery, Neil Bhutta, Kenneth P. Brevoort, and Glenn B. Canner (2010), "The 2009 HMDA Data: The Mortgage Market in a Time of Low Interest Rates and Economic Distress," Federal Reserve Bulletin, vol. 96 (December), pp. A39-A77, www.federalreserve.gov/pubs/bulletin/2010/default.htm. 
doubled, from 0.55 percent of the loan amount to 1.35 percent. ${ }^{10}$ In January 2015, the annual MIP was reduced to 0.85 percent for most borrowers, and the FHA share of homepurchase loans increased. In a supplementary analysis, we find that the reduced annual MIP increased the total number of home-purchase originations to lower-credit score, high-LTV borrowers. ${ }^{11}$

The remainder of table 1 provides additional details on the breakdown of one- to fourfamily home-purchase and refinance loans by lien and occupancy status and by property and loan type. ${ }^{12}$ Table 1 also provides the number of applications for and originations of home-improvement loans for one- to four-family properties, many of which are junior liens or unsecured, and loans for the purchase of multifamily properties (consisting of five or more units). Finally, the HMDA data include details about preapproval requests for homepurchase loans and loans purchased by reporting institutions during the reporting year, although the purchased loans may have been originated at any point in time. Lenders reported roughly 531,000 preapproval requests; roughly 67 percent of these requests turned into an actual loan application for a specific property in $2015 .{ }^{13}$ Table 1 also shows that, for 2015, lenders purchased 2.1 million loans from other institutions.

\section{Mortgage Outcomes by Income and by Race and Ethnicity}

A key attribute of the HMDA data is that they help policymakers and the broader public better understand the distribution of mortgage credit across different demographic groups. The next set of tables provides information on loan shares, product usage, denial rates and reasons, and mortgage pricing for population groups defined by applicant income, neighborhood income, and applicant race and ethnicity (tables 2-8). With the exception of table 8, which includes loans for manufactured homes (and contains information by type of loan rather than by applicant or neighborhood characteristic), these tables focus on firstlien home-purchase and refinance loans for one- to four-family, owner-occupied, site-built properties. As can be seen from table 1, such loans accounted for about 80 percent of all HMDA originations in 2015.

\section{The Distribution of Home Loans across Demographic Groups}

Table 2 shows different groups' shares of home-purchase and refinance loans and how these shares have changed over time. For example, black borrowers' share of homepurchase loans (conventional and nonconventional loans combined) was 5.5 percent in 2015, up from 5.2 percent in 2014 but still lower than its peak of 8.7 percent in 2006. Simi-

\footnotetext{
${ }^{10}$ Changes to the FHA's upfront and annual MIPs over time have been documented in Urban Institute, Housing Finance Policy Center (2014), Housing Finance at a Glance: A Monthly Chartbook (Washington: Urban Institute, March), www.urban.org/research/publication/housing-finance-glance-monthly-chartbook-1. A typical FHA home-purchase loan has an LTV of over 95 percent and a loan term in excess of 15 years. The upfront premium, on net, was unchanged between 2010 and 2013; it was briefly increased from 1.75 percent to 2.25 percent and lowered back to 1.00 percent in 2010, and then it was raised back to 1.75 percent in 2012 .

${ }^{11}$ See Neil Bhutta and Daniel Ringo (2016), "Changing FHA Mortgage Insurance Premiums and the Effects on Lending," FEDS Notes (Washington: Board of Governors of the Federal Reserve System, September 29), https://www.federalreserve.gov/econresdata/notes/feds-notes/2016/changing-fha-mortgage-insurance-pre miums-and-the-effects-on-lending-20160929.html.

${ }^{12}$ Note that under the regulations that govern HMDA reporting, many standalone junior-lien loans are not reported because either the lender does not know the purpose of the loan or the reasons cited for the loan are not ones that trigger a reporting requirement. Unless a junior lien is used for home purchase or explicitly for home improvements, or to refinance an existing lien, it is not reported under HMDA. Further, home equity lines of credit, many of which are junior liens and could also be used to help purchase a home, do not have to be reported in the HMDA data regardless of the purpose of the loan.

${ }^{13}$ Reporters can, but are not required to, report preapproval requests that they approve but are not acted on by the potential borrower.
} 
Table 2. Distribution of home loans, by purpose of loan, 2004-15

Percent except as noted

\begin{tabular}{|c|c|c|c|c|c|c|c|c|c|c|c|c|}
\hline $\begin{array}{l}\text { Characteristic of borrower } \\
\text { and of neighborhood }\end{array}$ & 2004 & 2005 & 2006 & 2007 & 2008 & 2009 & 2010 & 2011 & 2012 & 2013 & 2014 & 2015 \\
\hline \multicolumn{13}{|l|}{ A. Home purchase } \\
\hline \multicolumn{13}{|l|}{ Borrower race and ethnicity ${ }^{1}$} \\
\hline Asian & 4.8 & 5.0 & 4.5 & 4.5 & 4.9 & 5.3 & 5.5 & 5.2 & 5.3 & 5.7 & 5.4 & 5.3 \\
\hline Black or African American & 7.1 & 7.7 & 8.7 & 7.6 & 6.3 & 5.7 & 6.0 & 5.5 & 5.1 & 4.8 & 5.2 & 5.5 \\
\hline Hispanic white & 7.6 & 10.5 & 11.7 & 9.0 & 7.9 & 8.0 & 8.1 & 8.3 & 7.7 & 7.3 & 7.9 & 8.3 \\
\hline Non-Hispanic white & 57.1 & 61.7 & 61.2 & 65.4 & 67.5 & 67.9 & 67.6 & 68.7 & 70.0 & 70.2 & 69.1 & 68.1 \\
\hline Other minority ${ }^{2}$ & 1.4 & 1.3 & 1.1 & 1.0 & .9 & .9 & .9 & .8 & .8 & .7 & .8 & .8 \\
\hline Joint & 2.3 & 2.3 & 2.3 & 2.5 & 2.8 & 2.8 & 2.7 & 2.8 & 2.9 & 3.1 & 3.3 & 3.5 \\
\hline Missing & 19.8 & 11.5 & 10.5 & 10.1 & 9.6 & 9.3 & 9.1 & 8.6 & 8.2 & 8.2 & 8.3 & 8.5 \\
\hline All & 100 & 100 & 100 & 100 & 100 & 100 & 100 & 100 & 100 & 100 & 100 & 100 \\
\hline \multicolumn{13}{|l|}{ Borrower income $^{3}$} \\
\hline Low or moderate & 27.7 & 24.6 & 23.6 & 24.7 & 28.1 & 36.7 & 35.5 & 34.4 & 33.3 & 28.5 & 27.1 & 28.0 \\
\hline Middle & 26.9 & 25.7 & 24.7 & 25.2 & 27.1 & 26.7 & 25.6 & 25.2 & 25.2 & 25.2 & 25.6 & 26.1 \\
\hline High & 41.4 & 45.5 & 46.7 & 47.0 & 43.1 & 34.7 & 37.4 & 38.8 & 40.0 & 44.7 & 46.1 & 44.8 \\
\hline Income not used or not applicable & 4.0 & 4.2 & 5.0 & 3.1 & 1.7 & 1.9 & 1.5 & 1.6 & 1.5 & 1.6 & 1.3 & 1.2 \\
\hline All & 100 & 100 & 100 & 100 & 100 & 100 & 100 & 100 & 100 & 100 & 100 & 100 \\
\hline \multicolumn{13}{|l|}{ Neighborhood income ${ }^{4}$} \\
\hline Low or moderate & 14.5 & 15.1 & 15.7 & 14.4 & 13.1 & 12.6 & 12.1 & 11.0 & 12.8 & 12.7 & 13.3 & 13.5 \\
\hline Middle & 48.7 & 49.2 & 49.5 & 49.6 & 49.8 & 50.2 & 49.4 & 49.4 & 43.6 & 43.7 & 44.6 & 45.2 \\
\hline High & 35.8 & 34.7 & 33.7 & 35.1 & 35.9 & 35.8 & 37.7 & 39.1 & 43.2 & 43.2 & 41.8 & 41.0 \\
\hline All & 100 & 100 & 100 & 100 & 100 & 100 & 100 & 100 & 100 & 100 & 100 & 100 \\
\hline \multicolumn{13}{|l|}{ B. Refinance } \\
\hline \multicolumn{13}{|l|}{ Borrower race and ethnicity ${ }^{1}$} \\
\hline Asian & 3.5 & 2.9 & 3.0 & 3.1 & 3.1 & 4.1 & 5.2 & 5.4 & 5.5 & 4.7 & 4.3 & 5.0 \\
\hline Black or African American & 7.4 & 8.3 & 9.6 & 8.4 & 6.0 & 3.5 & 2.9 & 3.1 & 3.3 & 4.4 & 5.4 & 5.0 \\
\hline Hispanic white & 6.2 & 8.6 & 10.1 & 8.7 & 5.3 & 3.2 & 3.0 & 3.3 & 3.9 & 5.0 & 6.2 & 6.3 \\
\hline Non-Hispanic white & 57.2 & 60.9 & 59.6 & 62.7 & 70.7 & 74.6 & 74.3 & 73.5 & 72.5 & 70.5 & 67.8 & 67.2 \\
\hline Other minority ${ }^{2}$ & 1.4 & 1.4 & 1.3 & 1.1 & .8 & .6 & .5 & .6 & .6 & .7 & .9 & .8 \\
\hline Joint & 2.1 & 2.1 & 1.9 & 2.0 & 2.2 & 2.6 & 2.7 & 2.8 & 3.1 & 3.1 & 3.2 & 3.3 \\
\hline Missing & 22.1 & 15.7 & 14.6 & 14.1 & 11.9 & 11.4 & 11.4 & 11.3 & 11.1 & 11.6 & 12.2 & 12.4 \\
\hline All & 100 & 100 & 100 & 100 & 100 & 100 & 100 & 100 & 100 & 100 & 100 & 100 \\
\hline \multicolumn{13}{|l|}{ Borrower income $^{3}$} \\
\hline Low or moderate & 26.2 & 25.5 & 24.7 & 23.3 & 23.5 & 19.6 & 19.0 & 19.2 & 19.6 & 21.1 & 22.1 & 19.0 \\
\hline Middle & 26.3 & 26.8 & 26.1 & 25.6 & 25.5 & 22.5 & 22.5 & 21.3 & 21.8 & 21.7 & 21.9 & 21.0 \\
\hline High & 38.8 & 40.8 & 43.7 & 46.1 & 44.8 & 45.8 & 49.6 & 48.1 & 47.7 & 46.3 & 44.9 & 45.1 \\
\hline Income not used or not applicable & 8.7 & 6.9 & 5.5 & 5.0 & 6.2 & 12.1 & 8.9 & 11.4 & 10.9 & 10.9 & 11.1 & 14.9 \\
\hline All & 100 & 100 & 100 & 100 & 100 & 100 & 100 & 100 & 100 & 100 & 100 & 100 \\
\hline \multicolumn{13}{|l|}{ Neighborhood income ${ }^{4}$} \\
\hline Low or moderate & 15.3 & 16.5 & 17.9 & 16.1 & 11.9 & 7.7 & 7.2 & 7.4 & 10.1 & 12.1 & 13.3 & 12.3 \\
\hline Middle & 50.0 & 51.3 & 52.0 & 52.2 & 51.9 & 47.5 & 46.1 & 46.1 & 41.9 & 43.7 & 45.2 & 43.8 \\
\hline High & 33.9 & 31.6 & 29.4 & 31.0 & 35.2 & 43.5 & 46.0 & 46.0 & 47.6 & 43.9 & 41.2 & 43.7 \\
\hline All & 100 & 100 & 100 & 100 & 100 & 100 & 100 & 100 & 100 & 100 & 100 & 100 \\
\hline \multicolumn{13}{|l|}{ Memo } \\
\hline $\begin{array}{l}\text { Number of home-purchase loans } \\
\text { (thousands) }\end{array}$ & 4,660 & 4,836 & 4,298 & 3,331 & 2,533 & 2,391 & 2,157 & 2,018 & 2,284 & 2,638 & 2,741 & 3,124 \\
\hline Number of refinance loans (thousands) & 6,412 & 5,692 & 4,397 & 3,588 & 2,869 & 5,243 & 4,481 & 3,823 & 5,888 & 4,349 & 1,969 & 2,810 \\
\hline
\end{tabular}

Note: First-lien mortgages for one- to four-family, owner-occupied, site-built homes. Rows may not sum to 100 because of rounding or, for the distribution by neighborhood income, because property location is missing.

1 Applications are placed in one category for race and ethnicity. The application is designated as joint if one applicant was reported as white and the other was reported as one or more minority races or if the application is designated as white with one Hispanic applicant and one non-Hispanic applicant. If there are two applicants and each reports a different minority race, the application is designated as two or more minority races. If an applicant reports two races and one is white, that applicant is categorized under the minority race. Otherwise, the applicant is categorized under the first race reported. "Missing" refers to applications in which the race of the applicant(s) has not been reported or is not applicable or the application is categorized as white but ethnicity has not been reported.

2 Consists of applications by American Indians or Alaska Natives, Native Hawaiians or other Pacific Islanders, and borrowers reporting two or more minority races.

${ }^{3}$ The categories for the borrower-income group are as follows: Low- or moderate-income (or LMI) borrowers have income that is less than 80 percent of estimated current area median family income (AMFI), middle-income borrowers have income that is at least 80 percent and less than 120 percent of AMFI, and high-income borrowers have income that is at least 120 percent of AMFI.

${ }^{4}$ The categories for the neighborhood-income group are based on the ratio of census-tract median family income to area median family income from the 2006-10 American Community Survey data for 2012 and 2013 and from the 2000 census for 2004-11, and the three categories have the same cutoffs as the borrower-income groups (see note 3). 
larly, the Hispanic white share of home-purchase loans was 8.3 percent in 2015, up from 7.9 percent in 2014, although well below the 11.7 percent share seen in $2006 .{ }^{14}$ In a supplementary analysis, we use HMDA data matched to credit record data to better understand the decline in minority market shares since 2006, and we find that sharp reductions in lending to individuals with low credit scores can explain much of the decrease in black and Hispanic white market shares. ${ }^{15}$

In terms of borrower income, the share of home-purchase loans to LMI borrowers rose from 27.1 percent in 2014 to 28.0 percent in $2015 .{ }^{16}$ In accordance with definitions used by the federal bank supervisory agencies in enforcement of the Community Reinvestment Act, LMI borrowers are defined as those with incomes of less than 80 percent of estimated current area median family income (AMFI); AMFI is calculated based on the incomes of residents of the metropolitan area or nonmetropolitan portion of the state in which the loan-securing property is located. ${ }^{17}$

From 2014 to 2015, the share of home-purchase loans originated in high-income neighborhoods (census tracts) decreased slightly from 41.8 percent to 41.0 percent. ${ }^{18}$ LMI and middle-income tracts both saw small gains. In table 2, it is important to note that shares by neighborhood income in 2012 and thereafter are not perfectly comparable with those in 2011 and earlier because census-tract definitions and census-tract median family income estimates were revised in 2012. The current tract demographic measures are based on 2010 census data and 2006-10 American Community Survey data, whereas the 2004-11 data relied on 2000 census income and population data. ${ }^{19}$ In addition, the Office of Management and Budget published new metropolitan area delineations in 2014, so caution should be exercised in comparing relative income measurements between 2013 and later years.

\section{Average Loan Size by Demographic Group and Jumbo Lending}

Table 3 shows the average dollar value of home-purchase and refinance loans by different groups and how these averages have changed over time. All dollar amounts are reported in nominal terms. Overall, home-purchase dollar values follow the historical trend of home prices, rising during the mid-2000s, falling sharply through 2008 and 2009, and then beginning to recover since about 2011 . The trends differ substantially by race and ethnicity, however. The average home-purchase loan to a Hispanic white borrower in 2015 was for $\$ 209,000$, up from $\$ 198,000$ in 2014 but still well below the peak of $\$ 238,000$ in 2006. In contrast, the average home-purchase loan amount for a non-Hispanic white borrower was

\footnotetext{
${ }^{14}$ The bottom of table 2 provides the total loan counts for each year, and thus the number of loans to a given group in a given year can be easily derived. For example, the number of home-purchase loans to Asians in 2015 was about 164,000, derived by multiplying 3.1 million loans by 5.3 and then dividing by 100 .

${ }^{15}$ See Neil Bhutta and Daniel Ringo (2016), "Credit Availability and the Decline in Mortgage Lending to Minorities after the Housing Boom," FEDS Notes (Board of Governors of the Federal Reserve System, September 29), https://www.federalreserve.gov/econresdata/notes/feds-notes/2016/credit-availability-and-thedecline-in-mortgage-lending-to-minorities-after-the-housing-boom-20160929.html.

${ }^{16}$ Note that the sum of refinance shares across borrower-income groups is significantly less than 100 percent because income is not always relied on in underwriting decisions, particularly in recent years, which appears to reflect increased usage of nonconventional streamline refinance programs. Indeed, in 2015, about 89 percent of refinance loans for which borrower income was not reported were nonconventional.

${ }^{17}$ Middle-income borrowers have incomes of at least 80 percent and less than 120 percent of AMFI, and highincome borrowers have incomes of at least 120 percent of AMFI.

${ }^{18}$ Definitions for LMI, middle-income, and high-income neighborhoods are identical to those for LMI, middleincome, and high-income borrowers but are based on the ratio of census-tract median family income to AMFI measured from the 2006-10 American Community Survey data.

${ }^{19}$ For more information on the transition to the new census-tract data, see Robert B. Avery, Neil Bhutta, Kenneth P. Brevoort, and Glenn B. Canner (2012), "The Mortgage Market in 2011: Highlights from the Data Reported under the Home Mortgage Disclosure Act," Federal Reserve Bulletin, vol. 98 (December), pp. 1-46, www.federalreserve.gov/pubs/bulletin/2012/default.htm.
} 


\section{Table 3. Average value of home loans, by purpose of loan, 2004-15 \\ Thousands of dollars, nominal, except as noted}

\begin{tabular}{|c|c|c|c|c|c|c|c|c|c|c|c|c|}
\hline $\begin{array}{c}\text { Characteristic of borrower and of } \\
\text { neighborhood }\end{array}$ & 2004 & 2005 & 2006 & 2007 & 2008 & 2009 & 2010 & 2011 & 2012 & 2013 & 2014 & 2015 \\
\hline \multicolumn{13}{|l|}{ A. Home purchase } \\
\hline \multicolumn{13}{|l|}{ Borrower race and ethnicity ${ }^{1}$} \\
\hline Asian & 280 & 316 & 326 & 334 & 299 & 276 & 293 & 291 & 304 & 328 & 344 & 360 \\
\hline Black or African American & 166 & 183 & 197 & 197 & 184 & 172 & 174 & 174 & 179 & 193 & 199 & 209 \\
\hline Hispanic white & 189 & 224 & 238 & 220 & 186 & 168 & 168 & 168 & 176 & 190 & 198 & 209 \\
\hline Non-Hispanic white & 193 & 211 & 216 & 222 & 209 & 195 & 204 & 204 & 213 & 226 & 231 & 239 \\
\hline Other minority $^{2}$ & 206 & 240 & 257 & 245 & 216 & 196 & 201 & 198 & 206 & 219 & 229 & 241 \\
\hline Joint & 233 & 255 & 261 & 269 & 255 & 248 & 263 & 261 & 274 & 289 & 293 & 303 \\
\hline Missing & 216 & 248 & 261 & 280 & 265 & 242 & 256 & 262 & 279 & 298 & 293 & 303 \\
\hline \multicolumn{13}{|l|}{ Borrower income ${ }^{3}$} \\
\hline Low or moderate & 114 & 116 & 117 & 123 & 128 & 129 & 128 & 125 & 131 & 132 & 132 & 141 \\
\hline Middle & 165 & 170 & 170 & 176 & 182 & 187 & 189 & 184 & 192 & 194 & 193 & 204 \\
\hline High & 281 & 306 & 313 & 317 & 297 & 291 & 303 & 302 & 313 & 323 & 328 & 340 \\
\hline Income not used or not applicable & 208 & 235 & 254 & 266 & 218 & 195 & 214 & 225 & 233 & 260 & 273 & 315 \\
\hline \multicolumn{13}{|l|}{ Neighborhood income ${ }^{4}$} \\
\hline Low or moderate & 159 & 180 & 189 & 188 & 175 & 160 & 164 & 163 & 158 & 171 & 178 & 188 \\
\hline Middle & 172 & 190 & 197 & 196 & 186 & 174 & 177 & 173 & 178 & 191 & 196 & 206 \\
\hline High & 258 & 284 & 294 & 301 & 277 & 257 & 270 & 271 & 282 & 300 & 306 & 316 \\
\hline \multicolumn{13}{|l|}{ Memo } \\
\hline All home-purchase loans & 201 & 221 & 228 & 232 & 217 & 202 & 210 & 210 & 221 & 235 & 240 & 249 \\
\hline $\begin{array}{l}\text { Conventional jumbo loans (percent of } \\
\text { originations) })^{5}\end{array}$ & 11.2 & 12.7 & 9.4 & 6.8 & 2.3 & 1.3 & 1.7 & 2.2 & 2.9 & 4.0 & 4.8 & 5.3 \\
\hline $\begin{array}{l}\text { Conventional jumbo loans (percent of } \\
\text { loaned dollars) }\end{array}$ & 29.4 & 32.5 & 26.8 & 21.9 & 10.1 & 6.2 & 7.4 & 9.5 & 11.9 & 14.5 & 16.5 & 17.3 \\
\hline \multicolumn{13}{|l|}{ B. Refinance } \\
\hline \multicolumn{13}{|l|}{ Borrower race and ethnicity ${ }^{1}$} \\
\hline Asian & 274 & 325 & 370 & 368 & 321 & 298 & 313 & 309 & 308 & 304 & 341 & 363 \\
\hline Black or African American & 151 & 180 & 199 & 192 & 173 & 184 & 180 & 174 & 181 & 171 & 174 & 199 \\
\hline Hispanic white & 178 & 219 & 252 & 244 & 193 & 190 & 191 & 183 & 190 & 180 & 190 & 214 \\
\hline Non-Hispanic white & 180 & 205 & 221 & 222 & 205 & 209 & 210 & 208 & 212 & 206 & 216 & 239 \\
\hline Other minority ${ }^{2}$ & 190 & 229 & 269 & 258 & 211 & 217 & 218 & 207 & 213 & 201 & 213 & 240 \\
\hline Joint & 210 & 246 & 265 & 262 & 243 & 247 & 254 & 249 & 254 & 249 & 266 & 292 \\
\hline Missing & 194 & 226 & 246 & 250 & 242 & 243 & 248 & 253 & 253 & 244 & 245 & 268 \\
\hline \multicolumn{13}{|l|}{ Borrower income $^{3}$} \\
\hline Low or moderate & 114 & 124 & 124 & 126 & 129 & 138 & 133 & 128 & 135 & 128 & 123 & 136 \\
\hline Middle & 162 & 181 & 183 & 181 & 180 & 185 & 179 & 174 & 182 & 171 & 174 & 193 \\
\hline High & 256 & 294 & 320 & 311 & 275 & 268 & 274 & 280 & 277 & 276 & 301 & 324 \\
\hline Income not used or not applicable & 150 & 178 & 240 & 240 & 194 & 204 & 203 & 185 & 212 & 193 & 198 & 231 \\
\hline \multicolumn{13}{|l|}{ Neighborhood income ${ }^{4}$} \\
\hline Low or moderate & 142 & 169 & 188 & 185 & 164 & 172 & 172 & 167 & 163 & 153 & 157 & 182 \\
\hline Middle & 158 & 184 & 201 & 198 & 182 & 184 & 182 & 175 & 181 & 173 & 180 & 201 \\
\hline High & 245 & 282 & 313 & 311 & 272 & 259 & 265 & 269 & 269 & 270 & 290 & 311 \\
\hline \multicolumn{13}{|l|}{ Memo } \\
\hline All refinance loans & 185 & 212 & 232 & 231 & 212 & 216 & 220 & 218 & 221 & 213 & 222 & 247 \\
\hline $\begin{array}{l}\text { Conventional jumbo loans (percent of } \\
\text { originations) })^{5}\end{array}$ & 9.2 & 11.4 & 10.2 & 7.5 & 2.0 & .9 & 1.6 & 2.4 & 2.2 & 3.0 & 4.2 & 4.9 \\
\hline $\begin{array}{l}\text { Conventional jumbo loans (percent of } \\
\text { loaned dollars) }\end{array}$ & 25.8 & 29.6 & 28.3 & 23.0 & 9.0 & 4.1 & 6.9 & 10.7 & 9.1 & 12.7 & 16.5 & 16.8 \\
\hline
\end{tabular}

Note: First-lien mortgages for one- to four-family, owner-occupied, site-built homes.

1 See table 2, note 1.

2 See table 2, note 2 .

3 See table 2, note 3 .

4 See table 2, note 4

5 Fraction of loans that are conventional and have loan amounts in excess of the single-family conforming loan-size limits for eligibility for purchase by the government-sponsored enterprises. 
about $\$ 239,000$ in 2015 , higher than the pre-crisis peak in 2007 of about $\$ 222,000$. Asian borrowers took out the largest loans, averaging $\$ 360,000$ for home purchases and $\$ 363,000$ for refinancings in 2015, whereas loans to black borrowers averaged $\$ 209,000$ for home purchases and $\$ 199,000$ for refinancings. ${ }^{20}$

In terms of borrower income, for LMI borrowers, the average home-purchase loan amount increased to $\$ 141,000$ in 2015 from $\$ 132,000$ in 2014; it also increased by a similar magnitude for middle-income borrowers. High-income borrowers saw their average homepurchase loan value rise to $\$ 340,000$ in 2015 from $\$ 328,000$ in 2014. Average loan values increased across all borrower-income groups for refinance loans as well.

The increase in jumbo lending, coinciding with the general housing market recovery, continued in 2015. As table 3 shows, conventional jumbo loans - those with loan amounts in excess of the GSEs' conforming loan limits and no other government guaranteemade up 5.3 percent of all first-lien home-purchase loans for owner-occupied, one- to fourfamily, site-built homes in 2015, up from 4.8 percent in 2014. ${ }^{21}$ Among refinance loans, the conventional jumbo fraction increased to 4.9 percent from 4.2 percent in 2014. Because of their larger size, jumbo loans make up a correspondingly larger share of the dollar volume of mortgages, accounting for 17.3 percent of home-purchase loans and 16.8 percent of refinance loans in 2015. Since the financial crisis, most new jumbo loans have been held in the originating bank's portfolio, as the market for mortgage-backed securities without a government guarantee is thin. ${ }^{22}$

\section{Variation across Demographic Groups in Nonconventional Loan Use}

Table 4 shows that black and Hispanic white borrowers are much more likely to use nonconventional loans (FHA, VA, RHS, and FSA loans) than conventional loans compared with other racial and ethnic groups. In 2015, among home-purchase borrowers, 70 percent of blacks and 63 percent of Hispanic whites took out a nonconventional loan, whereas about 36 percent of non-Hispanic whites and just 17 percent of Asians did so. These numbers have declined from their peaks in 2009 and 2010, when well over threefourths of blacks and Hispanic whites, and over one-half of non-Hispanic whites, took out nonconventional loans.

Nonconventional usage is also more prevalent for borrowers with lower incomes and in neighborhoods with lower incomes. In 2015, about 53 percent of LMI home-purchase borrowers and 50 percent of those borrowing to purchase homes in LMI neighborhoods used nonconventional loans, compared with 26 percent of high-income borrowers and 29 percent of borrowers in high-income neighborhoods. While black and Hispanic white borrowers tend to have lower incomes, on average, than non-Hispanic white borrowers, the previously mentioned racial and ethnic differences in nonconventional loan use persist

\footnotetext{
${ }^{20}$ Median loan amounts (not shown in tables) followed similar trends as average loan amounts.

${ }^{21}$ A loan qualifies as jumbo in table 3 if the loan amount is above the GSEs' conforming loan-size limit for a single-family home for that year and location. The conforming loan-size limit was mostly uniform across the nation prior to 2008. The limits in Alaska, Hawaii, the U.S. Virgin Islands, and Guam are 50 percent higher than in the nation at large. For the years 2008 and thereafter, designated higher-cost areas have elevated limits. For 2015, the general conforming loan-size limit was $\$ 417,000$, and the maximum high-cost area loan-size limit was $\$ 625,500$ (and 50 percent higher in Alaska, Hawaii, the U.S. Virgin Islands, and Guam). Conforming loan-size limits increase with the number of units that make up the property, but the HMDA data do not differentiate between properties with anywhere from one to four units. Some loans in the table may therefore have been misclassified as jumbo despite being eligible for purchase by a GSE.

${ }^{22}$ See Neil Bhutta, Jack Popper, and Daniel R. Ringo (2015), "The 2014 Home Mortgage Disclosure Act Data," Federal Reserve Bulletin, vol. 101 (November), pp. 1-43, www.federalreserve.gov/pubs/bulletin/2015/default .htm.
} 


\section{Table 4. Nonconventional share of home loans, by purpose of loan, 2004-15}

Percent except as noted

\begin{tabular}{|c|c|c|c|c|c|c|c|c|c|c|c|c|}
\hline $\begin{array}{l}\text { Characteristic of borrower } \\
\text { and of neighborhood }\end{array}$ & 2004 & 2005 & 2006 & 2007 & 2008 & 2009 & 2010 & 2011 & 2012 & 2013 & 2014 & 2015 \\
\hline \multicolumn{13}{|l|}{ A. Home purchase } \\
\hline \multicolumn{13}{|l|}{ Borrower race and ethnicity ${ }^{1}$} \\
\hline Asian & 2.9 & 1.8 & 2.1 & 2.6 & 13.4 & 26.1 & 26.6 & 25.8 & 21.9 & 16.1 & 14.7 & 16.6 \\
\hline Black or African American & 21.7 & 14.3 & 13.6 & 21.7 & 64.1 & 82.0 & 82.9 & 80.3 & 77.2 & 70.8 & 68.0 & 70.2 \\
\hline Hispanic white & 13.7 & 7.5 & 7.0 & 12.4 & 51.4 & 75.4 & 77.0 & 74.1 & 70.7 & 63.1 & 59.5 & 62.6 \\
\hline Non-Hispanic white & 11.1 & 8.9 & 9.5 & 11.5 & 35.4 & 52.0 & 50.3 & 47.4 & 42.2 & 35.5 & 33.4 & 36.0 \\
\hline Other minority ${ }^{2}$ & 14.0 & 9.3 & 9.4 & 14.8 & 48.4 & 67.6 & 68.8 & 65.9 & 62.2 & 55.5 & 53.9 & 55.1 \\
\hline Joint & 16.9 & 12.8 & 14.4 & 17.2 & 46.4 & 59.4 & 56.3 & 53.6 & 48.9 & 42.1 & 41.3 & 43.7 \\
\hline Missing & 11.3 & 5.1 & 5.7 & 8.8 & 32.7 & 50.6 & 49.4 & 45.9 & 39.4 & 31.9 & 32.2 & 35.0 \\
\hline \multicolumn{13}{|l|}{ Borrower income ${ }^{3}$} \\
\hline Low or moderate & 20.3 & 15.2 & 14.9 & 16.0 & 46.1 & 65.3 & 66.6 & 64.5 & 59.7 & 52.5 & 50.3 & 53.3 \\
\hline Middle & 14.3 & 11.0 & 12.6 & 16.8 & 46.1 & 60.4 & 59.3 & 57.0 & 51.5 & 45.6 & 44.8 & 47.6 \\
\hline High & 5.3 & 3.9 & 4.9 & 7.5 & 26.7 & 38.5 & 37.2 & 34.3 & 29.5 & 25.1 & 24.2 & 26.3 \\
\hline \multicolumn{13}{|l|}{ Neighborhood income ${ }^{4}$} \\
\hline Low or moderate & 15.8 & 9.7 & 9.6 & 13.8 & 45.5 & 64.4 & 65.1 & 61.2 & 57.9 & 49.9 & 48.0 & 50.3 \\
\hline Middle & 14.1 & 10.2 & 10.8 & 14.2 & 42.7 & 59.8 & 59.4 & 56.9 & 52.0 & 44.7 & 43.0 & 45.6 \\
\hline High & 7.1 & 5.4 & 6.1 & 7.6 & 27.4 & 43.4 & 42.0 & 39.5 & 34.6 & 28.2 & 26.1 & 28.9 \\
\hline \multicolumn{13}{|l|}{ Memo } \\
\hline All borrowers & 11.9 & 8.5 & 9.0 & 11.8 & 37.6 & 54.4 & 53.4 & 50.5 & 45.2 & 38.2 & 36.6 & 39.4 \\
\hline \multicolumn{13}{|l|}{ B. Refinance } \\
\hline \multicolumn{13}{|l|}{ Borrower race and ethnicity ${ }^{1}$} \\
\hline Asian & 1.2 & .7 & .6 & 1.0 & 4.6 & 5.7 & 4.7 & 4.3 & 5.9 & 6.7 & 6.8 & 9.8 \\
\hline Black or African American & 11.1 & 5.8 & 4.4 & 10.2 & 39.2 & 53.8 & 42.0 & 37.8 & 38.6 & 37.1 & 39.1 & 49.4 \\
\hline Hispanic white & 5.6 & 2.6 & 1.9 & 3.9 & 20.5 & 36.2 & 28.1 & 22.9 & 26.9 & 25.8 & 21.2 & 32.0 \\
\hline Non-Hispanic white & 4.0 & 2.4 & 2.6 & 4.9 & 15.9 & 16.8 & 13.6 & 12.2 & 14.2 & 14.8 & 16.3 & 21.0 \\
\hline Other minority ${ }^{2}$ & 5.5 & 3.4 & 2.4 & 4.9 & 20.0 & 28.3 & 23.3 & 21.9 & 25.5 & 24.9 & 25.0 & 32.6 \\
\hline Joint & 7.5 & 3.7 & 3.4 & 6.2 & 19.5 & 21.1 & 16.6 & 16.3 & 20.1 & 20.5 & 25.5 & 28.0 \\
\hline Missing & 4.2 & 1.9 & 1.7 & 4.1 & 18.7 & 19.0 & 12.5 & 13.6 & 16.5 & 16.7 & 21.4 & 25.5 \\
\hline \multicolumn{13}{|l|}{ Borrower income $^{3}$} \\
\hline Low or moderate & 2.3 & 1.6 & 2.9 & 5.7 & 18.3 & 16.6 & 14.0 & 11.5 & 9.3 & 9.3 & 13.0 & 16.5 \\
\hline Middle & 1.7 & 1.3 & 2.7 & 6.2 & 19.6 & 13.2 & 12.2 & 10.9 & 8.9 & 9.5 & 13.2 & 14.8 \\
\hline High & .8 & .6 & 1.1 & 2.7 & 10.5 & 7.2 & 6.7 & 6.3 & 5.5 & 6.1 & 8.8 & 9.2 \\
\hline \multicolumn{13}{|l|}{ Neighborhood income ${ }^{4}$} \\
\hline Low or moderate & 5.9 & 3.2 & 2.9 & 6.3 & 24.6 & 31.3 & 23.1 & 19.7 & 22.2 & 22.1 & 22.4 & 29.5 \\
\hline Middle & 5.2 & 3.0 & 2.9 & 5.8 & 20.2 & 22.3 & 17.5 & 16.1 & 18.4 & 19.0 & 20.9 & 26.8 \\
\hline High & 2.9 & 1.7 & 1.6 & 3.0 & 11.3 & 12.1 & 10.0 & 9.3 & 11.7 & 12.4 & 14.5 & 18.4 \\
\hline \multicolumn{13}{|l|}{ Memo } \\
\hline All borrowers & 4.6 & 2.6 & 2.5 & 5.0 & 17.6 & 18.7 & 14.4 & 13.3 & 15.6 & 16.4 & 18.4 & 23.4 \\
\hline
\end{tabular}

Note: First-lien mortgages for one- to four-family, owner-occupied, site-built homes. Excludes applications where no credit decision was made. Nonconventional loans are those insured by the Federal Housing Administration or backed by guarantees from the U.S. Department of Veterans Affairs, the Farm Service Agency, or the Rural Housing Service.

1 See table 2, note 1.

2 See table 2, note 2

3 See table 2 , note 3 .

4 See table 2, note 4 . 
within income groups. ${ }^{23}$ With respect to refinance loans, minority and lower-income borrowers are again more likely to use nonconventional than conventional loans. In general, however, nonconventional loans are less prevalent in refinance lending. ${ }^{24}$

Greater reliance on nonconventional loans may reflect the relatively low down-payment requirements of the FHA and VA lending programs, which serve the needs of borrowers who have few assets to meet down-payment and closing-cost requirements. ${ }^{25}$ The patterns of product incidence could also reflect the behavior of lenders to some extent; for example, concerns have been raised about the possibility that lenders steer borrowers in certain neighborhoods toward such loans. ${ }^{26}$

\section{Denial Rates and Denial Reasons}

In 2015, the overall denial rate on applications for home-purchase loans of 12.1 percent, as well as the denial rate for refinance loan applications of 27.4 percent, was somewhat lower than in 2014 (table 5). ${ }^{27}$ Over longer horizons, denial rates have exhibited significant variation, and these changes differ by type of loan. For example, for conventional homepurchase loan applications, the denial rate of 10.8 percent in 2015 was 7.7 percentage points lower than in 2006, while for nonconventional home-purchase loan applications, the denial rate of 13.9 percent in 2015 was 1.8 percentage points higher than in 2006. Variations in raw denial rates over time reflect not only changes in credit standards, but also changes in the demand for credit and in the composition of borrowers applying for mortgages. For example, the denial rate on applications for conventional home-purchase loans was lower in 2015 than during the housing boom years, even though most measures of credit availability suggest that credit standards are tighter today. ${ }^{28}$ This result may stem from a relatively large drop in applications from riskier applicants.

As in past years, black, Hispanic white, and "other minority" borrowers had notably higher denial rates in 2015 than non-Hispanic white borrowers, while denial rates for Asian borrowers were more similar to those for non-Hispanic white borrowers. For example, the denial rates for conventional home-purchase loans were about 23 percent for black borrowers, 17 percent for Hispanic white borrowers, 12 percent for Asian borrowers, 18 percent for other minority borrowers, and 9 percent for non-Hispanic white borrowers.

Previous research and experience gained in the fair lending enforcement process show that differences in denial rates and in the incidence of higher-priced lending (the topic of the next subsection) among racial or ethnic groups stem, at least in part, from factors related to

\footnotetext{
${ }^{23}$ See Bhutta, Popper, and Ringo, "The 2014 Home Mortgage Disclosure Act Data," in note 22.

${ }^{24}$ The reported nonconventional share of refinance loans is lower than the true share for the groups categorized by borrower income because, in most nonconventional refinance loans, income is not reported. Thus, when income is reported on a refinance loan, the loan is likely to be conventional.

${ }^{25}$ Findings of the Federal Reserve Board's Survey of Consumer Finances for 2013 indicate that liquid asset levels and financial wealth holdings for minorities and lower-income groups are substantially smaller than they are for non-Hispanic white borrowers or higher-income populations. See Board of Governors of the Federal Reserve System, "2013 Survey of Consumer Finances,” webpage, www.federalreserve.gov/econresdata/scf/ scfindex.htm.

${ }^{26}$ See, for example, Glenn B. Canner, Stuart A. Gabriel, and J. Michael Woolley (1991), "Race, Default Risk and Mortgage Lending: A Study of the FHA and Conventional Loan Markets," Southern Economic Journal, vol. 58 (July), pp. 249-62.

${ }^{27}$ Denial rates are calculated as the number of denied loan applications divided by the total number of applications, excluding withdrawn applications and application files closed for incompleteness.

${ }^{28}$ Both the Mortgage Bankers Association and the Urban Institute publish indexes of mortgage credit availability suggesting that standards have been much tighter since the crisis. See Wei Li, Laurie Goodman, Ellen Seidman, Jim Parrott, Jun Zhu, and Bing Bai (2014), "Measuring Mortgage Credit Accessibility," working paper (Washington: Urban Institute, November), www.urban.org/research/publication/measuring-mortgage-creditaccessibility.
} 


\begin{tabular}{|c|c|c|c|c|c|c|c|c|c|c|c|c|}
\hline $\begin{array}{l}\text { Type of loan and } \\
\text { race and ethnicity } \\
\text { of borrower }\end{array}$ & 2004 & 2005 & 2006 & 2007 & 2008 & 2009 & 2010 & 2011 & 2012 & 2013 & 2014 & 2015 \\
\hline \multicolumn{13}{|l|}{ A. Home purchase } \\
\hline \multicolumn{13}{|c|}{ Conventional and nonconventional ${ }^{1}$} \\
\hline All applicants & 14.4 & 16.0 & 18.0 & 18.7 & 18.0 & 15.5 & 15.6 & 15.8 & 14.9 & 14.4 & 13.2 & 12.1 \\
\hline Asian & 13.7 & 15.9 & 16.9 & 17.5 & 19.2 & 16.3 & 15.8 & 16.5 & 15.8 & 15.3 & 14.0 & 12.6 \\
\hline Black or African American & 23.6 & 26.5 & 30.3 & 33.5 & 30.6 & 25.5 & 24.8 & 26.0 & 26.0 & 25.5 & 22.7 & 20.8 \\
\hline Hispanic white & 18.3 & 21.1 & 25.1 & 29.5 & 28.3 & 22.2 & 21.8 & 21.1 & 20.2 & 20.5 & 18.2 & 16.1 \\
\hline Non-Hispanic white & 11.1 & 12.2 & 12.9 & 13.3 & 14.0 & 12.8 & 12.9 & 13.1 & 12.5 & 12.0 & 11.0 & 10.0 \\
\hline Other minority ${ }^{2}$ & 19.4 & 20.8 & 24.0 & 26.7 & 25.5 & 21.2 & 21.9 & 20.9 & 20.8 & 21.2 & 18.9 & 17.2 \\
\hline \multicolumn{13}{|l|}{ Conventional only } \\
\hline All applicants & 14.6 & 16.3 & 18.5 & 19.0 & 18.3 & 15.8 & 15.2 & 15.1 & 13.6 & 12.9 & 11.8 & 10.8 \\
\hline Asian & 13.7 & 16.0 & 17.1 & 17.5 & 19.1 & 15.8 & 14.8 & 15.5 & 14.4 & 14.2 & 13.1 & 11.9 \\
\hline Black or African American & 25.0 & 27.8 & 31.9 & 35.7 & 37.6 & 35.8 & 33.6 & 33.2 & 32.0 & 28.5 & 24.7 & 23.3 \\
\hline Hispanic white & 18.6 & 21.4 & 25.7 & 30.5 & 32.5 & 26.9 & 24.9 & 24.2 & 22.4 & 21.5 & 18.8 & 17.2 \\
\hline Non-Hispanic white & 11.2 & 12.3 & 13.2 & 13.3 & 14.1 & 13.3 & 12.9 & 12.7 & 11.6 & 10.8 & 9.8 & 9.1 \\
\hline Other minority ${ }^{2}$ & 19.7 & 21.2 & 24.8 & 27.8 & 29.0 & 25.9 & 28.0 & 24.6 & 23.6 & 22.5 & 20.1 & 18.3 \\
\hline \multicolumn{13}{|l|}{ Nonconventional only ${ }^{1}$} \\
\hline All applicants & 13.3 & 12.5 & 12.1 & 16.2 & 17.4 & 15.3 & 16.0 & 16.5 & 16.3 & 16.8 & 15.7 & 13.9 \\
\hline Asian & 12.6 & 11.6 & 10.6 & 15.5 & 20.2 & 17.7 & 18.6 & 19.3 & 20.2 & 20.6 & 18.8 & 16.1 \\
\hline Black or African American & 17.7 & 16.8 & 16.2 & 22.8 & 25.3 & 22.6 & 22.7 & 23.9 & 24.0 & 24.1 & 21.8 & 19.7 \\
\hline Hispanic white & 16.3 & 17.2 & 15.7 & 20.5 & 23.1 & 20.4 & 20.7 & 19.9 & 19.3 & 19.9 & 17.8 & 15.5 \\
\hline Non-Hispanic white & 10.7 & 10.2 & 10.0 & 13.1 & 13.9 & 12.5 & 13.0 & 13.6 & 13.7 & 14.1 & 13.2 & 11.7 \\
\hline Other minority ${ }^{2}$ & 16.8 & 16.3 & 15.2 & 18.6 & 20.9 & 18.7 & 18.7 & 18.8 & 18.9 & 20.1 & 17.7 & 16.3 \\
\hline \multicolumn{13}{|l|}{ B. Refinance } \\
\hline \multicolumn{13}{|c|}{ Conventional and nonconventional ${ }^{1}$} \\
\hline All applicants & 29.5 & 32.6 & 35.4 & 39.6 & 37.7 & 24.0 & 23.3 & 23.8 & 19.9 & 23.3 & 30.9 & 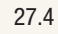 \\
\hline Asian & 18.8 & 23.5 & 27.5 & 32.6 & 32.5 & 21.4 & 19.5 & 20.1 & 17.3 & 21.0 & 27.9 & 23.8 \\
\hline Black or African American & 39.9 & 42.2 & 44.1 & 52.0 & 56.0 & 42.2 & 41.7 & 40.0 & 32.8 & 35.0 & 45.8 & 43.3 \\
\hline Hispanic white & 28.7 & 30.1 & 33.2 & 43.0 & 49.1 & 36.4 & 33.4 & 33.2 & 27.5 & 29.6 & 36.7 & 32.6 \\
\hline Non-Hispanic white & 24.1 & 26.9 & 30.1 & 33.7 & 32.2 & 20.7 & 20.6 & 21.3 & 17.8 & 20.5 & 27.5 & 24.1 \\
\hline Other minority ${ }^{2}$ & 33.7 & 35.5 & 40.6 & 52.0 & 57.4 & 37.3 & 35.3 & 34.4 & 30.0 & 32.1 & 41.6 & 40.2 \\
\hline \multicolumn{13}{|l|}{ Conventional only } \\
\hline All applicants & 30.1 & 32.9 & 35.6 & 39.9 & 37.0 & 22.1 & 21.3 & 22.3 & 19.4 & 22.5 & 29.5 & 26.4 \\
\hline Asian & 18.8 & 23.5 & 27.5 & 32.5 & 31.5 & 20.2 & 18.5 & 19.4 & 17.0 & 20.5 & 27.1 & 23.1 \\
\hline Black or African American & 41.7 & 43.0 & 44.7 & 53.3 & 60.9 & 48.6 & 41.4 & 40.6 & 34.8 & 36.0 & 47.0 & 47.8 \\
\hline Hispanic white & 29.3 & 30.2 & 33.3 & 43.2 & 50.2 & 38.9 & 33.6 & 33.5 & 28.9 & 30.6 & 37.3 & 34.7 \\
\hline Non-Hispanic white & 24.6 & 27.1 & 30.4 & 33.9 & 31.5 & 19.1 & 18.9 & 20.1 & 17.4 & 19.9 & 26.1 & 23.2 \\
\hline Other minority ${ }^{2}$ & 34.5 & 35.7 & 40.9 & 52.6 & 59.4 & 38.4 & 34.8 & 34.4 & 31.1 & 32.6 & 40.9 & 41.3 \\
\hline \multicolumn{13}{|l|}{ Nonconventional only ${ }^{1}$} \\
\hline All applicants & 15.0 & 20.1 & 21.9 & 31.6 & 40.9 & 31.1 & 33.3 & 32.2 & 22.2 & 26.7 & 36.6 & 30.3 \\
\hline Asian & 15.0 & 20.0 & 22.0 & 38.5 & 48.9 & 37.2 & 34.2 & 32.7 & 22.2 & 26.9 & 37.5 & 29.6 \\
\hline Black or African American & 17.5 & 23.6 & 24.6 & 33.7 & 43.5 & 35.1 & 42.2 & 39.1 & 29.5 & 33.1 & 43.9 & 37.8 \\
\hline Hispanic white & 15.7 & 23.6 & 26.3 & 34.6 & 43.4 & 31.4 & 33.0 & 32.3 & 23.3 & 26.6 & 34.5 & 27.7 \\
\hline Non-Hispanic white & 12.0 & 17.6 & 19.7 & 28.3 & 36.1 & 27.4 & 29.3 & 29.0 & 19.7 & 23.8 & 33.7 & 27.3 \\
\hline Other minority ${ }^{2}$ & 15.2 & 25.8 & 22.2 & 34.8 & 45.4 & 34.1 & 37.0 & 34.4 & 26.6 & 30.6 & 43.8 & 37.9 \\
\hline
\end{tabular}

Note: First-lien mortgages for one- to four-family, owner-occupied, site-built homes. For a description of how borrowers are categorized by race and ethnicity, see table 2 , note 1 .

1 Nonconventional loans are those insured by the Federal Housing Administration or backed by guarantees from the U.S. Department of Veterans Affairs, the Farm Service Agency, or the Rural Housing Service.

2 See table 2, note 2. 
credit risk that are not available in the HMDA data, such as credit history (including credit scores), ratio of total debt service payments to income (DTI), and LTV ratios. Differential costs of loan origination and the local competitive environment, as well as illegal discrimination, may also bear on the differences in pricing.

Despite these limitations, the HMDA data play an important role in fair lending enforcement. The data are regularly used by bank examiners to facilitate the fair lending examination and enforcement processes. When examiners for the federal banking agencies evaluate an institution's fair lending risk, they analyze HMDA price data and loan application outcomes in conjunction with other information and risk factors that can be drawn directly from loan files or electronic records maintained by lenders, as directed by the Interagency Fair Lending Examination Procedures. ${ }^{29}$ The availability of broader information allows the examiners to draw stronger conclusions about institution compliance with the fair lending laws.

Lenders can, but are not required to, report up to three reasons for denying a mortgage application, selecting from nine potential denial reasons (as shown in table 6). Among denied first-lien applications for one- to four-family, owner-occupied, site-built properties in 2015, about 74 percent of denied home-purchase applications and about 60 percent of denied refinance applications had at least one reported denial reason. The two most frequently cited denial reasons for both home-purchase and refinance loans were the applicant's credit history and DTI ratio (note that the sum across columns in table 6 can add up to more than 100 percent because lenders can cite more than one denial reason). For both home-purchase and refinance applications, the DTI ratio and collateral are more likely to be cited as denial reasons on conventional than nonconventional applications.

Denial reasons vary across racial and ethnic groups to some degree. For example, among denied home-purchase loan applications in 2015, credit history was cited as a denial reason for almost 27 percent of denied black applicants, 19 percent of denied Hispanic white applicants, 20 percent of denied non-Hispanic white applicants, and just 12 percent of denied Asian applicants. The DTI ratio was cited most often as a denial reason for Asian home-purchase applicants at 30 percent, compared with 22 percent for non-Hispanic white applicants at the lower end. Finally, collateral was cited most often as a denial reason on home-purchase applications for non-Hispanic white applicants at 15 percent, compared with 11 percent for black applicants.

\section{The Incidence of Higher-Priced Lending}

Current price-reporting rules under HMDA, in effect since October 2009, define higherpriced first-lien loans as those with an annual percentage rate (APR) of at least 1.5 percentage points above the average prime offer rate (APOR) for loans of a similar type (for example, a 30-year fixed-rate mortgage) ${ }^{30}$ The spread for junior-lien loans must be at least 3.5 percentage points for such loans to be considered higher priced. The APOR, which is published weekly by the Federal Financial Institutions Examination Council, is an estimate of the APR on loans being offered to high-quality prime borrowers based on the contract interest rates and discount points reported by Freddie Mac in its Primary Mortgage Market Survey. ${ }^{31}$

\footnotetext{
${ }^{29}$ The Interagency Fair Lending Examination Procedures are available at www.ffiec.gov/PDF/fairlend.pdf.

${ }^{30}$ For more information about the rule changes related to higher-priced lending and the ways in which they affect the incidence of reported higher-priced lending over time, see Avery and others, "The 2009 HMDA Data," in note 9 .

${ }^{31}$ See Freddie Mac, "Mortgage Rates Survey," webpage, www.freddiemac.com/pmms; and Federal Financial
} 


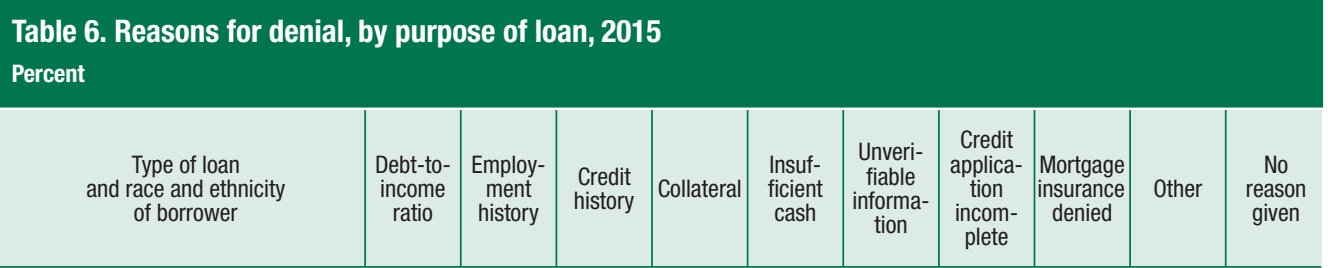

A. Home purchase

Conventional and nonconventional ${ }^{1}$

\begin{tabular}{|c|c|c|c|c|c|c|c|c|c|c|}
\hline All applicants & 23.4 & 3.8 & 20.4 & 13.7 & 6.9 & 5.2 & 9.3 & .6 & 10.1 & 26.3 \\
\hline Asian & 30.5 & 4.8 & 12.3 & 12.5 & 8.5 & 8.5 & 11.8 & 6 & 11.0 & 21.5 \\
\hline Black or African American & 25.3 & 3.0 & 26.6 & 10.5 & 7.8 & 4.9 & 6.8 & .6 & 9.9 & 27.4 \\
\hline Hispanic white & 25.3 & 4.1 & 19.4 & 12.1 & 6.9 & 6.1 & 6.9 & .5 & 12.0 & 28.4 \\
\hline Non-Hispanic white & 22.2 & 3.8 & 20.1 & 14.7 & 6.5 & 4.9 & 9.4 & 6 & 9.8 & 26.5 \\
\hline 0ther minority ${ }^{2}$ & 25.5 & 3.5 & 24.3 & 11.4 & 8.0 & 5.2 & 7.9 & .4 & 10.2 & 25.6 \\
\hline \multicolumn{11}{|l|}{ onventional only } \\
\hline All applicants & 24.8 & 3.2 & 20.5 & 15.7 & 7.5 & 5.4 & 10.0 & 1.0 & 9.9 & 22.8 \\
\hline Asian & 30.6 & 4.3 & 11.3 & 13.4 & 9.0 & 8.7 & 13.0 & .7 & 10.8 & 20.2 \\
\hline Black or African American & 26.0 & 2.4 & 33.0 & 13.0 & 8.9 & 4.0 & 5.8 & 1.6 & 10.4 & 21.6 \\
\hline Hispanic white & 27.0 & 3.1 & 21.7 & 15.3 & 8.0 & 5.6 & 6.9 & 1.0 & 13.0 & 22.7 \\
\hline Non-Hispanic white & 23.9 & 3.2 & 19.8 & 16.5 & 7.1 & 5.2 & 10.1 & 1.0 & 9.3 & 23.5 \\
\hline 0ther minority ${ }^{2}$ & 26.8 & 3.4 & 27.0 & 11.6 & 9.3 & 5.6 & 7.7 & .8 & 10.3 & 23.8 \\
\hline \multicolumn{11}{|l|}{ Ionconventional only ${ }^{1}$} \\
\hline All applicants & 21.7 & 4.4 & 20.3 & 11.4 & 6.1 & 5.0 & 8.4 & .1 & 10.3 & 30.4 \\
\hline Asian & 30.0 & 6.5 & 15.9 & 9.3 & 6.8 & 7.7 & 7.8 & .07 & 11.8 & 26.5 \\
\hline Black or African American & 24.9 & 3.4 & 23.2 & 9.2 & 7.3 & 5.3 & 7.4 & .1 & 9.6 & 30.5 \\
\hline Hispanic white & 24.2 & 4.7 & 17.7 & 10.0 & 6.1 & 6.4 & 6.9 & .1 & 11.4 & 32.3 \\
\hline Non-Hispanic white & 19.9 & 4.6 & 20.4 & 12.3 & 5.7 & 4.4 & 8.6 & .1 & 10.5 & 30.6 \\
\hline Other minority ${ }^{2}$ & 24.3 & 3.6 & 21.8 & 11.2 & 6.7 & 4.9 & 8.2 & .1 & 10.1 & 27.2 \\
\hline
\end{tabular}

B. Refinance

Conventional and nonconventional'

\begin{tabular}{|c|c|c|c|c|c|c|c|c|c|c|}
\hline All applicants & 14.8 & .9 & 16.8 & 13.9 & 2.7 & 3.6 & 11.0 & .1 & 7.8 & 39.8 \\
\hline Asian & 23.1 & 1.4 & 13.5 & 11.2 & 3.3 & 5.4 & 10.7 & .1 & 9.3 & 35.8 \\
\hline Black or African American & 11.0 & .5 & 18.8 & 11.3 & 2.8 & 2.7 & 8.4 & .1 & 7.4 & 47.6 \\
\hline Hispanic white & 18.6 & 1.0 & 19.5 & 10.3 & 3.5 & 4.0 & 9.1 & .1 & 9.1 & 38.5 \\
\hline Non-Hispanic white & 14.7 & .9 & 16.1 & 14.9 & 2.6 & 3.7 & 10.5 & .1 & 7.7 & 40.1 \\
\hline 0ther minority ${ }^{2}$ & 13.7 & .7 & 16.1 & 9.9 & 2.3 & 3.8 & 8.8 & .1 & 7.5 & 48.2 \\
\hline \multicolumn{11}{|l|}{ onventional only } \\
\hline All applicants & 17.5 & .9 & 17.4 & 14.9 & 2.7 & 4.2 & 9.7 & .1 & 8.0 & 37.5 \\
\hline Asian & 24.9 & 1.4 & 13.4 & 11.9 & 3.5 & 5.7 & 10.3 & .1 & 9.2 & 34.2 \\
\hline Black or African American & 13.3 & .5 & 19.9 & 12.0 & 2.5 & 3.2 & 6.7 & .2 & 7.6 & 46.9 \\
\hline Hispanic white & 21.3 & 1.0 & 20.1 & 11.2 & 3.5 & 4.4 & 7.7 & .1 & 9.0 & 37.1 \\
\hline Non-Hispanic white & 17.2 & 1.0 & 16.8 & 16.0 & 2.6 & 4.3 & 9.4 & .1 & 7.9 & 37.5 \\
\hline 0ther minority ${ }^{2}$ & 15.9 & .8 & 17.3 & 10.5 & 2.3 & 4.6 & 7.6 & .1 & 7.8 & 45.9 \\
\hline \multicolumn{11}{|l|}{ lonconventional only ${ }^{1}$} \\
\hline All applicants & 7.8 & .7 & 15.1 & 11.3 & 2.7 & 2.0 & 14.2 & .03 & 7.3 & 46.0 \\
\hline Asian & 12.0 & .9 & 14.0 & 6.9 & 2.2 & 3.2 & 13.4 & .0 & 9.7 & 46.5 \\
\hline Black or African American & 7.4 & .4 & 17.1 & 10.1 & 3.3 & 1.8 & 11.1 & .02 & 7.1 & 48.7 \\
\hline Hispanic white & 10.9 & .9 & 18.0 & 7.7 & 3.4 & 3.0 & 13.0 & .06 & 9.6 & 42.5 \\
\hline Non-Hispanic white & 7.3 & .7 & 14.0 & 11.7 & 2.5 & 2.0 & 13.8 & .04 & 7.1 & 47.5 \\
\hline Other minority ${ }^{2}$ & 8.7 & .6 & 13.2 & 8.5 & 2.3 & 1.9 & 11.5 & .0 & 6.8 & 53.5 \\
\hline
\end{tabular}

Note: Denied first-lien mortgage applications for one- to four-family, owner-occupied, site-built homes. Columns sum to more than 100 because lenders may report up to three denial reasons. For a description of how borrowers are categorized by race and ethnicity, see table 2 , note 1 .

1 See table 5 , note 1 .

2 See table 2, note 2. 
In 2015, the fraction of home-purchase loans (again, first liens for one- to four-family, owner-occupied, site-built properties) above the higher-priced threshold decreased to 7.6 percent from 11.6 percent in 2014 (as shown in table 7.A). This decrease stemmed from a drop in the higher-priced share of nonconventional loans from 26 percent to 14.5 percent, while the higher-priced share of conventional loans increased slightly, from 3.1 percent to 3.2 percent.

Table 7.A also shows that, in 2015 as well as earlier years, black and Hispanic white borrowers had the highest incidences of higher-priced loans within both the conventional and nonconventional loan types. This table provides the raw rates of higher-priced lending by group from 2004 to 2015, but, as discussed in detail in previous Bulletin articles, the raw rates reported in the public HMDA data can be difficult to compare over longer time horizons for two main reasons. First, a different price-reporting rule was in place prior to October 2009, with the spread between a mortgage's APR and the rate on a Treasury bond of comparable term (rather than the APOR) reported if it rose above 3 percentage points. ${ }^{32}$ Second, the previous price-reporting rule created unintended distortions in reporting over time (which is why the reporting rule was changed), so data from years prior to 2009 are not even directly comparable from year to year. ${ }^{33}$

Table 7.B provides adjusted rates of higher-priced lending that are intended to be more comparable over time. Using the dates of application and origination (which are not released in the public HMDA data files) and assuming all loans are 30-year fixed-rate mortgages, we can estimate the APR of loans that were originated under the old pricing rule. ${ }^{34}$ This estimated APR can then be compared with the APOR, as is done under the new price-reporting rule. Finally, because the implied threshold spread over the APOR during the previous reporting regime got to as high as about 2.5 percentage points, table 7.B reports the fraction of loans with an estimated APR spread over the APOR (or the actual reported spread for loans made under the new rules) of at least 2.5 percentage points - rather than 1.5 percentage points, as in table 7.A. ${ }^{35}$ Higher-priced lending by this measure virtually disappeared by 2008 and has not reemerged, likely reflecting the lack of subprime mortgage lending.

The higher-priced fraction of FHA home-purchase loans was about 22 percent in 2015 (table 8). In contrast, about 1 percent of VA and FSA/RHS home-purchase loans were higher priced. In 2014, the higher-priced fraction of FHA home-purchase loans was much higher, at around 44 percent. The January 2015 reduction in the FHA's annual MIP appears to have moved many FHA home-purchase loans under the reporting threshold. The June 2013 increase in the term length over which the annual MIP must be paid remained in effect, however. As a result, the fraction of FHA home-purchase loans priced over the reporting threshold in 2015 was still substantially higher than before the 2013 rule change, despite a lower annual MIP.

\footnotetext{
32 The reporting threshold for junior liens was 5 percentage points.

${ }^{33}$ These distortions are related to the fact that changes in long-term Treasury rates do not always lead to parallel changes in mortgage rates. For a discussion of how the old rule could produce misleading data about trends in higher-priced lending, see Neil Bhutta and Daniel R. Ringo (2014), "The 2013 Home Mortgage Disclosure Act Data," Federal Reserve Bulletin, vol. 100 (November), pp. 1-32, www.federalreserve.gov/pubs/bulletin/2014/ default.htm.

34 The assumption that all mortgages were fixed rate likely understates the extent of higher-priced lending during the early years of the housing boom. During this period, adjustable-rate mortgages were quite prevalent, and the APRs on such loans are tied to even shorter-term Treasury rates than are the APRs on fixed-rate mortgages. Thus, when the yield curve is relatively steep, as it was in 2004, the bar for adjustable-rate mortgages to be reported as higher priced would have been even higher than for fixed-rate mortgages.

${ }^{35}$ For a more detailed discussion of this adjustment technique, see Avery and others, "The 2009 HMDA Data," in note 9 .
} 


\begin{tabular}{|c|c|c|c|c|c|c|c|c|c|c|c|c|}
\hline $\begin{array}{l}\text { Type of loan and } \\
\text { race and ethnicity } \\
\text { of borrower }\end{array}$ & 2004 & 2005 & 2006 & 2007 & 2008 & 2009 & 2010 & 2011 & 2012 & 2013 & 2014 & 2015 \\
\hline \multicolumn{13}{|l|}{ Home purchase } \\
\hline \multicolumn{13}{|c|}{ Conventional and nonconventional ${ }^{1}$} \\
\hline All borrowers & 9.8 & 22.5 & 23.2 & 12.7 & 8.1 & 4.6 & 2.2 & 3.3 & 3.1 & 7.1 & 11.6 & 7.6 \\
\hline Asian & 5.5 & 16.3 & 16.4 & 7.6 & 4.0 & 2.4 & 1.0 & 1.5 & 1.4 & 3.1 & 5.2 & 3.6 \\
\hline Black or African American & 24.3 & 46.7 & 46.4 & 27.6 & 14.5 & 7.1 & 3.0 & 5.0 & 5.3 & 14.3 & 25.6 & 16.2 \\
\hline Hispanic white & 17.5 & 42.0 & 43.3 & 25.9 & 15.8 & 8.1 & 3.9 & 6.1 & 5.9 & 16.9 & 28.4 & 18.5 \\
\hline Non-Hispanic white & 7.8 & 15.5 & 16.0 & 9.6 & 7.2 & 4.3 & 2.2 & 3.1 & 2.9 & 6.2 & 9.5 & 6.2 \\
\hline Other minority ${ }^{2}$ & 14.4 & 30.3 & 30.7 & 16.1 & 9.1 & 5.3 & 2.3 & 3.5 & 3.4 & 8.8 & 13.6 & 8.9 \\
\hline \multicolumn{13}{|l|}{ Conventional only } \\
\hline All borrowers & 11.0 & 24.5 & 25.3 & 14.0 & 7.3 & 4.6 & 3.3 & 3.8 & 3.2 & 2.9 & 3.1 & 3.2 \\
\hline Asian & 5.6 & 16.6 & 16.7 & 7.7 & 3.3 & 1.9 & 1.0 & 1.3 & 1.2 & 1.1 & 1.5 & 2.1 \\
\hline Black or African American & 30.6 & 54.1 & 53.4 & 34.0 & 17.4 & 8.7 & 6.1 & 8.0 & 6.7 & 6.1 & 7.7 & 6.8 \\
\hline Hispanic white & 20.0 & 45.3 & 46.3 & 28.9 & 17.7 & 11.0 & 9.6 & 10.7 & 8.7 & 7.3 & 6.5 & 8.3 \\
\hline Non-Hispanic white & 8.6 & 16.9 & 17.5 & 10.5 & 6.5 & 4.8 & 3.4 & 3.9 & 3.2 & 2.9 & 3.0 & 2.9 \\
\hline Other minority ${ }^{2}$ & 16.1 & 33.3 & 33.6 & 18.5 & 9.5 & 6.7 & 4.6 & 5.5 & 5.1 & 4.9 & 5.0 & 4.9 \\
\hline \multicolumn{13}{|l|}{ Nonconventional only ${ }^{1}$} \\
\hline All borrowers & 1.2 & .9 & 1.8 & 3.0 & 9.5 & 4.6 & 1.3 & 2.7 & 3.0 & 13.9 & 26.2 & 14.5 \\
\hline Asian & 2.4 & .6 & .8 & 1.3 & 8.2 & 3.9 & .8 & 2.0 & 1.9 & 13.4 & 26.2 & 11.4 \\
\hline Black or African American & 1.4 & 1.6 & 2.5 & 4.5 & 12.8 & 6.8 & 2.4 & 4.3 & 4.9 & 17.6 & 34.0 & 20.2 \\
\hline Hispanic white & 2.0 & 1.4 & 3.5 & 4.5 & 14.0 & 7.1 & 2.2 & 4.5 & 4.8 & 22.5 & 43.3 & 24.6 \\
\hline Non-Hispanic white & 1.0 & .7 & 1.5 & 2.5 & 8.4 & 3.9 & 1.0 & 2.3 & 2.6 & 12.1 & 22.4 & 12.2 \\
\hline Other minority ${ }^{2}$ & 4.4 & .7 & 2.1 & 2.4 & 8.8 & 4.7 & 1.2 & 2.5 & 2.4 & 11.9 & 20.9 & 12.2 \\
\hline \multicolumn{13}{|l|}{ Refinance } \\
\hline \multicolumn{13}{|c|}{ Conventional and nonconventional ${ }^{1}$} \\
\hline All borrowers & 14.5 & 25.0 & 30.3 & 21.0 & 10.9 & 3.8 & 1.8 & 2.1 & 1.5 & 1.9 & 3.3 & 2.5 \\
\hline Asian & 5.8 & 15.1 & 19.5 & 12.5 & 3.1 & .9 & .4 & .5 & .4 & .5 & 1.1 & .7 \\
\hline Black or African American & 30.0 & 46.2 & 50.7 & 38.1 & 22.8 & 9.0 & 6.5 & 6.8 & 4.1 & 3.8 & 5.6 & 5.1 \\
\hline Hispanic white & 18.2 & 32.6 & 36.9 & 26.5 & 15.1 & 7.0 & 4.4 & 4.4 & 2.6 & 3.1 & 4.7 & 3.9 \\
\hline Non-Hispanic white & 12.3 & 20.4 & 25.0 & 17.6 & 10.2 & 3.7 & 1.8 & 2.2 & 1.5 & 2.0 & 3.3 & 2.4 \\
\hline Other minority ${ }^{2}$ & 17.6 & 26.9 & 32.3 & 23.8 & 13.9 & 4.7 & 2.6 & 2.6 & 2.0 & 2.2 & 3.1 & 2.8 \\
\hline \multicolumn{13}{|l|}{ Conventional only } \\
\hline All borrowers & 15.2 & 25.7 & 31.0 & 21.8 & 10.4 & 3.1 & 1.3 & 1.5 & 1.2 & 1.5 & 2.2 & 1.6 \\
\hline Asian & 5.8 & 15.2 & 19.6 & 12.5 & 2.9 & .7 & .2 & .3 & .3 & .3 & .7 & .4 \\
\hline Black or African American & 33.7 & 49.0 & 52.8 & 41.5 & 27.6 & 9.9 & 4.0 & 4.2 & 2.9 & 3.3 & 3.8 & 3.1 \\
\hline Hispanic white & 19.2 & 33.4 & 37.5 & 27.3 & 16.0 & 7.2 & 3.3 & 3.3 & 2.3 & 2.4 & 2.8 & 2.4 \\
\hline Non-Hispanic white & 12.8 & 20.9 & 25.6 & 18.2 & 9.8 & 3.1 & 1.3 & 1.6 & 1.2 & 1.6 & 2.3 & 1.7 \\
\hline Other minority ${ }^{2}$ & 18.2 & 27.7 & 32.9 & 24.5 & 14.7 & 4.8 & 1.9 & 2.2 & 1.7 & 2.0 & 2.1 & 2.0 \\
\hline \multicolumn{13}{|l|}{ Nonconventional only ${ }^{1}$} \\
\hline All borrowers & 1.5 & .9 & 3.1 & 6.6 & 13.2 & 6.7 & 4.9 & 5.9 & 3.2 & 3.9 & 8.1 & 5.4 \\
\hline Asian & 3.6 & 2.1 & 2.5 & 4.9 & 8.9 & 4.8 & 3.1 & 4.0 & 1.8 & 2.6 & 7.1 & 3.3 \\
\hline Black or African American & 1.0 & 1.2 & 4.1 & 7.8 & 15.2 & 8.2 & 9.8 & 10.9 & 6.0 & 4.6 & 8.3 & 7.1 \\
\hline Hispanic white & 2.0 & .9 & 2.6 & 6.2 & 11.6 & 6.6 & 7.3 & 7.9 & 3.6 & 5.1 & 12.1 & 7.0 \\
\hline Non-Hispanic white & 1.3 & .7 & 2.8 & 6.0 & 12.1 & 6.5 & 4.6 & 5.9 & 3.3 & 4.2 & 8.6 & 5.4 \\
\hline Other minority ${ }^{2}$ & 8.1 & 3.9 & 9.6 & 9.9 & 10.5 & 4.5 & 4.6 & 4.3 & 2.9 & 2.8 & 5.9 & 4.4 \\
\hline
\end{tabular}

Note: First-lien mortgages for one- to four-family, owner-occupied, site-built homes. For a description of how borrowers are categorized by race and ethnicity, see table 2, note 1.

1 See table 5 , note 1

2 See table 2 , note 2 . 


\section{Table 7. Incidence of higher-priced lending, by purpose of loan, 2004-15 \\ B. Adjusted \\ Percent}

\begin{tabular}{|c|c|c|c|c|c|c|c|c|c|c|c|c|}
\hline $\begin{array}{c}\text { Type of loan and race and ethnicity of } \\
\text { borrower }\end{array}$ & 2004 & 2005 & 2006 & 2007 & 2008 & 2009 & 2010 & 2011 & 2012 & 2013 & 2014 & 2015 \\
\hline \multicolumn{13}{|l|}{ Home purchase } \\
\hline \multicolumn{13}{|l|}{ Conventional and nonconventional ${ }^{1}$} \\
\hline All borrowers & 7.4 & 18.3 & 17.1 & 6.3 & 1.3 & 1.3 & .6 & .8 & .8 & .7 & .8 & .7 \\
\hline Asian & 3.8 & 13.0 & 11.4 & 3.1 & .5 & .5 & .3 & .3 & .3 & .3 & .4 & .5 \\
\hline Black or African American & 19.3 & 40.3 & 38.5 & 16.7 & 1.9 & 1.3 & .6 & .7 & .9 & 1.0 & 1.2 & 1.2 \\
\hline Hispanic white & 12.3 & 34.5 & 32.8 & 13.0 & 2.1 & 1.4 & 1.0 & 1.3 & 1.6 & 1.5 & 1.6 & 1.5 \\
\hline Non-Hispanic white & 5.8 & 12.1 & 10.9 & 4.3 & 1.3 & 1.4 & .7 & .8 & .8 & .7 & .7 & .6 \\
\hline Other minority ${ }^{2}$ & 10.5 & 24.7 & 22.7 & 8.0 & 1.5 & 1.4 & .8 & .9 & 1.1 & .9 & .9 & .9 \\
\hline \multicolumn{13}{|l|}{ Conventional only } \\
\hline All borrowers & 8.2 & 20.0 & 18.7 & 7.1 & 1.9 & 2.3 & 1.3 & 1.4 & 1.2 & .9 & .8 & .8 \\
\hline Asian & 3.8 & 13.3 & 11.6 & 3.2 & .5 & .6 & .3 & .4 & .4 & .3 & .4 & .5 \\
\hline Black or African American & 24.4 & 46.9 & 44.5 & 21.2 & 4.7 & 4.0 & 2.6 & 2.6 & 2.7 & 1.7 & 1.4 & 1.8 \\
\hline Hispanic white & 14.0 & 37.2 & 35.2 & 14.8 & 3.9 & 4.6 & 3.9 & 4.1 & 4.5 & 2.8 & 2.3 & 2.8 \\
\hline Non-Hispanic white & 6.5 & 13.2 & 12.0 & 4.9 & 1.9 & 2.6 & 1.3 & 1.5 & 1.2 & .8 & .7 & .7 \\
\hline Other minority ${ }^{2}$ & 11.6 & 27.2 & 25.0 & 9.3 & 2.7 & 3.7 & 2.3 & 2.5 & 2.6 & 1.7 & 1.3 & 1.5 \\
\hline \multicolumn{13}{|l|}{ Nonconventional only ${ }^{1}$} \\
\hline All borrowers & .9 & .3 & .2 & .3 & .4 & .4 & .1 & .2 & .3 & .5 & .7 & .5 \\
\hline Asian & 2.2 & .3 & .1 & .2 & .2 & .2 & .1 & .2 & .2 & .3 & .4 & .2 \\
\hline Black or African American & 1.0 & .5 & .3 & .6 & .4 & .7 & .2 & .3 & .3 & .8 & 1.1 & 1.0 \\
\hline Hispanic white & 1.6 & .3 & .3 & .2 & .5 & .4 & .1 & .3 & .3 & .8 & 1.1 & .7 \\
\hline Non-Hispanic white & .8 & .2 & .2 & .2 & .3 & .3 & .1 & .2 & .3 & .5 & .7 & .5 \\
\hline Other minority ${ }^{2}$ & 3.9 & .3 & .2 & .2 & .3 & .3 & .1 & .1 & .2 & .3 & .6 & .4 \\
\hline \multicolumn{13}{|l|}{ Refinance } \\
\hline \multicolumn{13}{|l|}{ Conventional and nonconventional ${ }^{1}$} \\
\hline All borrowers & 11.3 & 20.1 & 21.3 & 12.7 & 4.3 & 1.4 & .6 & .8 & .7 & .7 & 1.0 & .6 \\
\hline Asian & 4.1 & 12.2 & 12.1 & 5.4 & .8 & .2 & .1 & .2 & .1 & .1 & .2 & .1 \\
\hline Black or African American & 24.3 & 38.5 & 39.0 & 26.4 & 10.6 & 3.5 & 2.6 & 3.3 & 2.5 & 1.6 & 2.0 & 1.3 \\
\hline Hispanic white & 13.4 & 27.0 & 25.8 & 14.8 & 5.6 & 2.5 & 1.8 & 1.8 & 1.1 & .9 & 1.1 & .7 \\
\hline Non-Hispanic white & 9.5 & 15.9 & 16.9 & 10.3 & 4.1 & 1.4 & .6 & .8 & .7 & .7 & 1.1 & .6 \\
\hline Other minority ${ }^{2}$ & 13.2 & 22.0 & 22.3 & 14.5 & 7.1 & 2.1 & .9 & 1.1 & 1.1 & .8 & 1.1 & .7 \\
\hline \multicolumn{13}{|l|}{ Conventional only } \\
\hline All borrowers & 11.8 & 20.7 & 21.9 & 13.3 & 5.1 & 1.5 & .5 & .6 & .4 & .4 & .7 & .5 \\
\hline Asian & 4.1 & 12.3 & 12.1 & 5.4 & .9 & .2 & .1 & .1 & .0 & .0 & .1 & .1 \\
\hline Black or African American & 27.3 & 40.8 & 40.7 & 29.4 & 17.1 & 6.3 & 2.0 & 1.8 & 1.0 & 1.0 & 1.4 & 1.1 \\
\hline Hispanic white & 14.1 & 27.7 & 26.2 & 15.4 & 6.9 & 3.5 & 1.4 & 1.3 & .8 & .7 & .8 & .8 \\
\hline Non-Hispanic white & 9.9 & 16.3 & 17.3 & 10.9 & 4.8 & 1.6 & .5 & .6 & .4 & .5 & .8 & .5 \\
\hline Other minority ${ }^{2}$ & 13.6 & 22.6 & 22.7 & 14.9 & 8.3 & 2.8 & .9 & .9 & .7 & .7 & .7 & .6 \\
\hline \multicolumn{13}{|l|}{ Nonconventional only ${ }^{1}$} \\
\hline All borrowers & 1.0 & .6 & .7 & .5 & .4 & .5 & 1.2 & 2.5 & 2.4 & 1.8 & 2.4 & .9 \\
\hline Asian & 2.9 & 1.8 & 1.3 & 1.4 & .5 & .3 & .5 & 1.5 & 1.4 & 1.1 & 1.9 & .4 \\
\hline Black or African American & .6 & .8 & 1.2 & .6 & .5 & 1.1 & 3.5 & 5.9 & 4.9 & 2.6 & 3.0 & 1.5 \\
\hline Hispanic white & 1.4 & .4 & .3 & .6 & .7 & .8 & 2.8 & 3.5 & 1.9 & 1.3 & 2.0 & .6 \\
\hline Non-Hispanic white & .8 & .4 & .4 & .3 & .4 & .5 & 1.0 & 2.4 & 2.5 & 2.1 & 2.8 & 1.0 \\
\hline Other minority ${ }^{2}$ & 6.3 & 3.4 & 7.8 & 6.3 & 1.9 & .4 & 1.1 & 2.0 & 2.2 & 1.2 & 2.2 & .8 \\
\hline
\end{tabular}

Note: First-lien mortgages for one- to four-family, owner-occupied, site-built homes. For a description of how borrowers are categorized by race and ethnicity, see table 2, note 1. See text for details on how adjusted incidences of higher-priced lending are calculated.

1 See table 5 , note 1

2 See table 2, note 2 


\begin{tabular}{|c|c|c|c|c|c|c|c|c|c|}
\hline \multirow{3}{*}{ Purpose and type of loan } & \multirow{3}{*}{$\begin{array}{c}\text { Total } \\
\text { number }\end{array}$} & \multicolumn{8}{|c|}{ Loans with APOR spread above 1.5 percentage points ${ }^{1}$} \\
\hline & & \multirow{2}{*}{ Number } & \multirow{2}{*}{ Percent } & \multicolumn{6}{|c|}{ Distribution, by percentage points of APOR spread } \\
\hline & & & & $1.5-1.99$ & $2-2.49$ & $2.5-2.99$ & 3-3.99 & $4-4.99$ & 5 or more \\
\hline \multicolumn{10}{|l|}{ Site-built homes } \\
\hline \multicolumn{10}{|l|}{ Home purchase } \\
\hline Conventional & $1,894,090$ & 59,959 & 3.2 & 53.7 & 20.3 & 10.2 & 8.8 & 3.4 & 3.6 \\
\hline $\mathrm{FHA}^{2}$ & 793,828 & 173,157 & 21.8 & 78.0 & 18.4 & 2.4 & .9 & .14 & .12 \\
\hline VA/RHS/FSA ${ }^{3}$ & 435,792 & 5,080 & 1.2 & 84.5 & 7.8 & 1.6 & 3.8 & 2.0 & .3 \\
\hline \multicolumn{10}{|l|}{ Refinance } \\
\hline Conventional & $2,151,796$ & 33,573 & 1.6 & 51.1 & 18.6 & 10.1 & 11.2 & 5.1 & 3.9 \\
\hline $\mathrm{FHA}^{2}$ & 391,651 & 34,582 & 8.8 & 70.0 & 13.2 & 7.9 & 6.2 & .5 & 2.2 \\
\hline VA/RHS/FSA ${ }^{3}$ & 266,758 & 1,009 & .4 & 92.3 & 3.9 & .7 & 2.2 & .8 & .2 \\
\hline \multicolumn{10}{|l|}{ Manufactured homes } \\
\hline \multicolumn{10}{|l|}{ Home purchase } \\
\hline Conventional & 56,155 & 43,331 & 77.2 & 6.7 & 4.9 & 7.3 & 13.1 & 10.8 & 57.3 \\
\hline $\mathrm{FHA}^{2}$ & 15,408 & 8,383 & 54.4 & 57.2 & 25.4 & 6.5 & 1.7 & .6 & 8.7 \\
\hline VA/RHS/FSA ${ }^{3}$ & 4,372 & 181 & 4.1 & 90.1 & 7.7 & .6 & 1.7 & 0 & 0 \\
\hline \multicolumn{10}{|l|}{ Refinance } \\
\hline Conventional & 20,591 & 5,869 & 28.5 & 27.2 & 15.3 & 13.3 & 18.3 & 11.4 & 14.6 \\
\hline $\mathrm{FHA}^{2}$ & 6,783 & 1,529 & 22.5 & 68.7 & 19.3 & 6.7 & 4.4 & .3 & .7 \\
\hline VA/RHS/FSA ${ }^{3}$ & 3,439 & 59 & 1.7 & 88.1 & 11.9 & 0 & 0 & 0 & 0 \\
\hline
\end{tabular}

Note: First-lien mortgages for one- to four-family owner-occupied homes.

1 Average prime offer rate (APOR) spread is the difference between the annual percentage rate on the loan and the APOR for loans of a similar type published weekly by the Federal Financial Institutions Examination Council. The threshold for first-lien loans is a spread of 1.5 percentage points.

2 Loans insured by the Federal Housing Administration.

${ }^{3}$ Loans backed by guarantees from the U.S. Department of Veterans Affairs, the Rural Housing Service, or the Farm Service Agency.

\section{HOEPA Loans}

Under the Home Ownership and Equity Protection Act (HOEPA), certain types of mortgage loans that have interest rates or fees above specified levels are subject to additional consumer protections, such as special disclosures and restrictions on loan features. New rules extending HOEPA's protections from refinance and home equity loans to also include home-purchase loans and home equity lines of credit became effective on January 10, 2014. These rules also added new protections for high-cost mortgages, such as a pre-loan counseling requirement for borrowers.

The new rules also changed the benchmark used to identify high-cost loans that are covered by HOEPA's protections. Instead of using the yield on Treasury securities, highcost loans are identified by comparing a loan's APR with the APOR. HOEPA coverage now applies to first liens with an APR more than 6.5 percentage points above the APOR. If the loan is a junior lien or the loan amount is less than $\$ 50,000$ and the loan is secured by personal property (such as a manufactured home), then the high-cost threshold is 8.5 percentage points above the APOR. Prior to 2014, HOEPA's protections were triggered if the loan's APR exceeded 8 percentage points above the rate on a Treasury security of 


\begin{tabular}{|c|c|c|c|c|c|c|c|c|c|c|c|c|}
\hline $\begin{array}{l}\text { Loans by purpose, lien status, property } \\
\text { type, and amount }\end{array}$ & 2004 & 2005 & 2006 & 2007 & 2008 & 2009 & 2010 & 2011 & 2012 & 2013 & 2014 & 2015 \\
\hline HOEPA loans (total) & 24,437 & 35,985 & 15,195 & 10,780 & 8,577 & 6,446 & 3,407 & 2,373 & 2,193 & 1,868 & 1,271 & 1,248 \\
\hline \multicolumn{13}{|l|}{ Loan purpose } \\
\hline Home purchase & 0 & 0 & 0 & 0 & 0 & 0 & 0 & 0 & 0 & 0 & 31.3 & 39.5 \\
\hline Home improvement & 37.7 & 26.1 & 42.4 & 45.4 & 30.5 & 31.1 & 32.6 & 32.3 & 31.5 & 30.1 & 17.8 & 14.9 \\
\hline Refinance & 62.3 & 73.9 & 57.6 & 54.6 & 69.5 & 68.9 & 67.4 & 67.7 & 68.5 & 69.9 & 50.9 & 45.6 \\
\hline \multicolumn{13}{|l|}{ Lien status } \\
\hline First & 55.5 & 60.5 & 53.6 & 52.8 & 78.5 & 84.1 & 83.9 & 82.8 & 84.6 & 84.2 & 90.4 & 88.4 \\
\hline Junior & 44.5 & 39.5 & 46.4 & 47.2 & 21.5 & 15.9 & 16.1 & 17.2 & 15.4 & 15.8 & 9.6 & 11.6 \\
\hline \multicolumn{13}{|l|}{ Property type } \\
\hline Site built & 88.0 & 91.8 & 83.7 & 81.0 & 72.7 & 67.8 & 68.3 & 65.7 & 65.7 & 68.8 & 75.4 & 83.3 \\
\hline Manufactured home & 12.0 & 8.2 & 16.3 & 19.0 & 27.3 & 32.2 & 31.7 & 34.3 & 34.3 & 31.2 & 24.6 & 16.7 \\
\hline \multicolumn{13}{|l|}{ Loan amount } \\
\hline Less than $\$ 50,000$ & 72.4 & 48.4 & 72.1 & 74.3 & 66.7 & 72.5 & 76.5 & 77.8 & 75.6 & 71.3 & 52.8 & 36.9 \\
\hline Greater than $\$ 50,000$ & 27.6 & 51.6 & 27.9 & 25.7 & 33.3 & 27.5 & 23.5 & 22.2 & 24.4 & 28.7 & 47.2 & 63.1 \\
\hline
\end{tabular}

Note: Mortgages for one- to four-family homes. HOEPA loans are mortgages with terms that triggered the additional protections provided by the Home Ownership and Equity Protection Act.

similar term for first liens, and 10 percentage points for junior liens. Finally, under the new rules, HOEPA coverage is also triggered if the points and fees exceed certain thresholds. ${ }^{36}$

While HOEPA loans were never a large fraction of the mortgage market, they have become even rarer since the housing boom. In 2005, lenders reported nearly 36,000 HOEPA loans (table 9). In 2015, the total was only 1,248 loans (about the same as in 2014), despite the extension of HOEPA protections to home-purchase loans.

\section{Lending Institutions}

In 2015, there were 6,913 reporting institutions (table 10). The total consisted of 3,954 banks and thrifts (hereafter, banks), of which 3,209 were small, defined as having assets of less than $\$ 1$ billion; 1,971 credit unions; 132 mortgage companies affiliated with depositories (banks and credit unions); and 856 independent mortgage companies. ${ }^{37}$ Banks collectively accounted for about 42 percent of all reported mortgage originations; independent mortgage companies, about 44 percent; credit unions, 9 percent; and affiliates, the remainder.

Many institutions report little activity. About 44 percent of institutions (3,071 out of 6,913) reported fewer than 100 mortgage originations in 2015, accounting for about 122,000

\footnotetext{
${ }^{36}$ Under the new rules, a loan is also considered high cost if the points and fees exceed 5 percent of the total loan amount for a loan amount equal to or more than $\$ 20,000$ and 8 percent of the total loan amount or $\$ 1,000$ for a loan less than \$20,000, with the loan amounts adjusted annually for inflation from the base year of 2014 .

${ }^{37}$ Data on bank assets were drawn from the Federal Deposit Insurance Corporation Reports of Condition and Income. The $\$ 1$ billion threshold is based on the combined assets of all banks within a given banking organization. Data available in the HMDA Reporter Panel (available at https://www.ffiec.gov/hmda/hmdaflat.htm) can be used to help identify the various types of institutions. Affiliate institutions include all mortgage companies known to be wholly or partially owned by a depository - that is, institutions for which the "other lender code" in the Reporter Panel equals 1, 2, or 5. Most credit unions report to the National Credit Union Administration, except four large credit unions (Boeing Employees Credit Union, Navy Federal Credit Union, Pentagon Federal Credit Union, and State Employees Credit Union), which report to the Consumer Financial Protection Bureau.
} 


\begin{tabular}{|c|c|c|c|c|c|c|}
\hline \multirow[b]{2}{*}{ Institutions and type of activity } & \multicolumn{6}{|c|}{ Type of institution ${ }^{1}$} \\
\hline & Small bank & Large bank & Credit union & $\begin{array}{l}\text { Affiliated } \\
\text { mortgage } \\
\text { company }\end{array}$ & $\begin{array}{l}\text { Independent } \\
\text { mortgage } \\
\text { company }\end{array}$ & All \\
\hline Number of institutions & 3,209 & 745 & 1,971 & 132 & 856 & 6,913 \\
\hline Applications (thousands) & 858 & 3,963 & 1,104 & 551 & 5,619 & 12,094 \\
\hline Originations (thousands) & 621 & 2,470 & 670 & 359 & 3,285 & 7,404 \\
\hline Purchases (thousands) & 24 & 1,107 & 19 & 185 & 767 & 2,102 \\
\hline Number of institutions with fewer than 100 loans & 1,765 & 129 & 1,067 & 27 & 83 & 3,071 \\
\hline Originations (thousands) & 71.6 & 5.6 & 40.7 & 1.1 & 3.1 & 122.1 \\
\hline Number of institutions with fewer than 25 loans & 611 & 41 & 419 & 9 & 40 & 1,120 \\
\hline Originations (thousands) & 7.5 & .5 & 5.2 & .1 & .5 & 13.8 \\
\hline Home-purchase loans (thousands)² & 234 & 929 & 202 & 197 & 1,562 & 3,124 \\
\hline Conventional & 72.2 & 74.9 & 85.2 & 57.1 & 47.7 & 60.6 \\
\hline Higher-priced share of conventional loans & 11.0 & 1.8 & 5.3 & 1.4 & 2.4 & 3.2 \\
\hline LMI borrower ${ }^{3}$ & 30.1 & 23.7 & 26.6 & 30.8 & 30.0 & 28.0 \\
\hline LMI neighborhood ${ }^{4}$ & 12.1 & 11.8 & 12.9 & 12.5 & 14.9 & 13.5 \\
\hline Non-Hispanic white ${ }^{5}$ & 81.1 & 69.6 & 69.9 & 71.1 & 64.7 & 68.1 \\
\hline Minority borrower ${ }^{5}$ & 11.8 & 17.9 & 14.8 & 16.2 & 23.4 & 19.9 \\
\hline Sold ${ }^{6}$ & 72.7 & 72.2 & 47.3 & 96.2 & 97.8 & 84.8 \\
\hline Refinance loans (thousands) ${ }^{2}$ & 161 & 932 & 251 & 122 & 1,344 & 2,810 \\
\hline Conventional & 82.9 & 90.9 & 95.8 & 76.2 & 62.3 & 76.6 \\
\hline Higher-priced share of conventional loans & 7.6 & 1.2 & 2.7 & .6 & .7 & 1.6 \\
\hline LMI borrower ${ }^{3}$ & 20.1 & 20.2 & 23.2 & 17.9 & 17.4 & 19.0 \\
\hline LMI neighborhood ${ }^{4}$ & 10.0 & 11.1 & 12.9 & 10.9 & 13.3 & 12.3 \\
\hline Non-Hispanic white ${ }^{5}$ & 83.6 & 69.5 & 70.0 & 70.2 & 62.8 & 67.2 \\
\hline Minority borrower ${ }^{5}$ & 8.1 & 16.5 & 14.6 & 14.8 & 19.3 & 17.1 \\
\hline Sold ${ }^{6}$ & 71.3 & 72.0 & 37.4 & 95.6 & 98.9 & 82.7 \\
\hline \multicolumn{7}{|c|}{$\begin{array}{l}1 \text { Small banks consist of those banks with assets (including the assets of all other banks in the same banking organization) of less than } \\
\$ 1 \text { billion at the end of 2015. Affiliated mortgage companies are nondepository mortgage companies owned by or affiliated with a banking } \\
\text { organization or credit union. }\end{array}$} \\
\hline \multicolumn{7}{|c|}{2 First-lien mortgages for one- to four-family, owner-occupied, site-built homes. } \\
\hline \multicolumn{7}{|l|}{3 See table 2, note 3.} \\
\hline \multicolumn{7}{|l|}{${ }^{4}$ See table 2 , note 4.} \\
\hline \multicolumn{7}{|c|}{5 See table 2, note 1. "Minority borrower" refers to nonwhite (excluding joint or missing) or Hispanic white applicants. } \\
\hline \multicolumn{7}{|c|}{$\begin{array}{l}{ }^{6} \text { Excludes originations made in the last quarter of the year because the incidence of loan sales tends to decline for loans originated toward the } \\
\text { end of the year, as lenders report a loan as sold only if the sale occurs within the same year as origination. }\end{array}$} \\
\hline $\begin{array}{l}\text { Source: FFIEC HMDA data; bank asset data drawn } \\
\text { (https://www.fdic.gov). }\end{array}$ & Federal Depo & Insurance & ration Rep & s of Condit & d Income & \\
\hline
\end{tabular}

originations, or 2 percent of all originations. About 16 percent of institutions originated fewer than 25 loans, in total accounting for about one-fifth of 1 percent of all originations.

Table 10 provides several other statistics to help compare the lending patterns of different types of institutions in 2015, and we discuss some highlights here. First, depositories tend to originate a significantly higher fraction of conventional loans than nondepositories. Second, in 2015, small banks and credit unions accounted for a highly disproportionate share of conventional higher-priced loans. About 11 percent of conventional homepurchase loans for one- to four-family, owner-occupied, site-built properties originated by small banks were higher priced, as were over 5 percent of such loans originated by credit unions. In contrast, about 2 percent of such loans originated by other types of institutions were higher priced. The numbers for both home-purchase and refinance lending imply that, 
even though small banks and credit unions accounted for less than 18 percent of conventional home-purchase and refinance loans, they originated over 47 percent of conventional higher-priced loans. ${ }^{38}$

Third, small banks and credit unions are significantly less likely to originate mortgages to minority borrowers, compared with independent mortgage companies, but are more similar to independent mortgage companies in terms of their share of lending to LMI borrowers and neighborhoods.

Fourth, the HMDA data provide information on whether originated loans were sold within the same calendar year and the type of institution to which they were sold, such as one of the GSEs or a banking institution (see appendix A for a full list of purchaser types). Table 10 displays the fraction of loans sold within the calendar year, as opposed to being held in portfolio. ${ }^{39}$ Nondepositories sold virtually all of their loans in 2015. In contrast, credit unions sold less than one-half of the home-purchase loans they originated and a little more than one-third of the refinance loans they originated. That said, portfolio lending among depositories has declined significantly over time.

Table 11 lists the top 25 reporting institutions according to their total number of originations, along with the same set of lending characteristics as those listed in table $10 .{ }^{40}$ Wells Fargo reported the most originations, with about 436,000. ${ }^{41}$ The next-highest total was for Quicken Loans, followed by Bank of America and JPMorgan Chase (JPMC). Overall, the top 25 lenders accounted for about 33 percent of all loan originations in 2015, down slightly from 34 percent in 2014. These same firms also purchased over 1.2 million loans from other lending institutions during 2015 (these loans could have been originated in 2015 or in earlier years).

The top institutions differ significantly in their lending patterns. For example, about 95 percent of JPMC's home-purchase loans were conventional, compared with less than 50 percent for Quicken Loans. Regarding loan sales, Navy Federal Credit Union sold only about 51 percent of its home-purchase originations, whereas the average across the top 25 institutions was about 83 percent. Finally, the composition of borrowers varied across the top 25 institutions. For some institutions, one-third or more of home-purchase borrowers

${ }^{38}$ The share of conventional loans originated by, for example, small banks can be calculated from the data in table 10. To obtain the small bank share of conventional home-purchase loans, multiply the number of homepurchase loans small banks originated $(234,000)$ by the percentage that were conventional $(72.2)$, and divide this result by the product of the total number of home-purchase loans (3.1 million) and the percentage that were conventional (60.6). To calculate the share of higher-priced conventional home-purchase loans originated by small banks, divide the number of such loans originated by small banks (11 percent of 72.2 percent of $234,000)$ by their total number ( 3.2 percent of 60.6 percent of 3.1 million). Similar calculations apply to refinance loans and other institution types.

${ }^{39}$ Because loan sales are recorded in the HMDA data only if the loans are originated and sold in the same calendar year, loans originated toward the end of the year are less likely to be reported as sold. For that reason, statistics on loan sales are computed using only loans originated during the first three quarters of the year.

${ }^{40}$ Some institutions may be part of a larger organization; however, the data in table 11 are at the reporter level. Because affiliate activity has declined markedly since the housing boom, a top 25 list at the organization level is not likely to be significantly different.

${ }^{41}$ Notably, market shares derived from the HMDA data can differ markedly from market shares based on information compiled by Inside Mortgage Finance. For HMDA reporting purposes, institutions report only mortgage applications in which they make the credit decision. Under HMDA, if an application is approved by a third party (such as a correspondent) rather than the lending institution, then that party reports the loan as its own origination and the lending institution reports the loan as a purchased loan. Alternatively, if a third party forwards an application to the lending institution for approval, then the lending institution reports the application under HMDA (and the third party does not report anything). In contrast, Inside Mortgage Finance considers loans to have been originated by the acquiring institution even if a third party makes the credit decision. Thus, many of the larger lending organizations that work with sizable networks of correspondents report considerable volumes of purchased loans in the HMDA data, while Inside Mortgage Finance considers many of these purchased loans to be originations. 


\begin{tabular}{|c|c|c|c|c|c|c|c|c|c|c|c|}
\hline \multirow[b]{2}{*}{ Respondent } & \multirow[b]{2}{*}{$\begin{array}{l}\text { Institution } \\
\text { type }^{1}\end{array}$} & \multirow[b]{2}{*}{$\begin{array}{c}\text { Total } \\
\text { origin- } \\
\text { ations } \\
\text { (thousands) }\end{array}$} & \multirow[b]{2}{*}{$\begin{array}{c}\text { Total } \\
\text { purchases } \\
\text { (thousands) }\end{array}$} & \multicolumn{8}{|c|}{ Home-purchase loans ${ }^{2}$} \\
\hline & & & & $\begin{array}{c}\text { Number } \\
\text { (thous- } \\
\text { ands) }\end{array}$ & $\begin{array}{l}\text { Con- } \\
\text { ven- } \\
\text { tional }\end{array}$ & $\begin{array}{l}\text { Higher } \\
\text { priced }^{3}\end{array}$ & $\begin{array}{c}\text { LMI } \\
\text { bor- } \\
\text { rower }\end{array}$ & $\begin{array}{c}\text { LMI } \\
\text { neigh- } \\
\text { bor- } \\
\text { hood }^{5}\end{array}$ & $\begin{array}{c}\text { Non- } \\
\text { Hispanic } \\
\text { white }^{6}\end{array}$ & $\begin{array}{c}\text { Minority } \\
\text { borrower }\end{array}$ & Sold ${ }^{7}$ \\
\hline Wells Fargo Bank, NA & Large bank & 436 & 468 & 156 & 76.8 & 6 & 18.5 & 11.3 & 67.1 & 20.6 & 76.3 \\
\hline Quicken Loans, Inc. & Ind. mort. co. & 366 & 0 & 66 & 49.0 & .3 & 28.8 & 13.6 & 54.6 & 13.2 & 99.9 \\
\hline Bank of America, NA & Large bank & 170 & 27 & 47 & 84.9 & .0 & 18.5 & 11.3 & 61.5 & 28.5 & 60.4 \\
\hline JPMorgan Chase Bank, NA & Large bank & 170 & 212 & 56 & 95.0 & 6 & 13.5 & 8.8 & 63.8 & 21.2 & 37.8 \\
\hline U.S. Bank, NA & Large bank & 113 & 143 & 32 & 80.0 & 1.1 & 28.3 & 11.7 & 68.6 & 12.1 & 78.3 \\
\hline Freedom Mortgage Corp. & Ind. mort. co. & 100 & 66 & 15 & 46.7 & .2 & 26.3 & 14.1 & 62.2 & 24.4 & 97.8 \\
\hline loanDepot.com & Ind. mort. co. & 99 & 0 & 27 & 56.2 & 1.6 & 19.1 & 13.5 & 52.2 & 26.4 & 100.0 \\
\hline Flagstar Bank, FSB & Large bank & 98 & 16 & 44 & 58.1 & 1.7 & 25.5 & 12.9 & 66.8 & 25.1 & 95.4 \\
\hline Caliber Home Loans, Inc. & Ind. mort. co. & 70 & 31 & 44 & 53.5 & 2.5 & 32.2 & 16.0 & 60.3 & 23.2 & 94.2 \\
\hline PNC Bank, NA & Large bank & 69 & 0 & 20 & 68.1 & .0 & 34.8 & 14.4 & 62.9 & 15.2 & 85.2 \\
\hline Citibank, NA & Large bank & 67 & 26 & 22 & 96.6 & .0 & 12.4 & 13.3 & 43.8 & 30.9 & 52.7 \\
\hline Navy Federal Credit Union & Credit union & 63 & 0 & 30 & 40.5 & 25.4 & 22.3 & 12.9 & 53.4 & 21.9 & 50.8 \\
\hline Nationstar Mortgage & Ind. mort. co. & 60 & 28 & 1 & 80.0 & .9 & 22.8 & 11.1 & 58.1 & 23.4 & 99.9 \\
\hline Stearns Lending, Inc. & Ind. mort. co. & 59 & 37 & 30 & 47.5 & 1.5 & 32.0 & 16.8 & 63.2 & 26.7 & 100.0 \\
\hline $\begin{array}{l}\text { PrimeLending, a } \\
\text { PlainsCapital Company }\end{array}$ & $\begin{array}{l}\text { Affiliated } \\
\text { mort. co. }\end{array}$ & 58 & 1 & 41 & 55.3 & 2.2 & 30.3 & 12.8 & 70.9 & 16.2 & 99.9 \\
\hline Guild Mortgage Co. & Ind. mort. co. & 56 & 7 & 34 & 43.4 & 3.5 & 31.8 & 18.0 & 59.3 & 20.9 & 99.7 \\
\hline Ditech Financial LLC & Ind. mort. co. & 54 & 73 & 4 & 68.0 & .5 & 26.8 & 13.6 & 71.7 & 18.2 & 99.9 \\
\hline Shore Mortgage & Ind. mort. co. & 50 & 0 & 21 & 82.1 & 1.7 & 28.1 & 14.3 & 62.5 & 29.6 & 100.0 \\
\hline Guaranteed Rate, Inc. & Ind. mort. co. & 50 & 0 & 27 & 74.1 & 1.0 & 23.4 & 13.0 & 73.3 & 15.5 & 100.0 \\
\hline $\begin{array}{l}\text { Fairway Independent } \\
\text { Mortgage Corp. }\end{array}$ & Ind. mort. co. & 49 & 1 & 36 & 48.3 & 2.3 & 34.5 & 13.8 & 72.8 & 17.6 & 99.7 \\
\hline $\begin{array}{l}\text { Branch Banking and } \\
\text { Trust Co. }\end{array}$ & Large bank & 48 & 48 & 19 & 74.7 & .2 & 26.9 & 12.5 & 69.6 & 10.8 & 72.9 \\
\hline Regions Bank & Large bank & 45 & 0 & 16 & 66.9 & 3.4 & 29.6 & 12.7 & 75.7 & 19.9 & 64.6 \\
\hline SunTrust Mortgage, Inc. & $\begin{array}{l}\text { Affiliated } \\
\text { mort. co. }\end{array}$ & 43 & 45 & 15 & 86.3 & .1 & 17.9 & 10.4 & 63.0 & 16.9 & 96.3 \\
\hline Academy Mortgage Corp. & Ind. mort. co. & 41 & 0 & 29 & 42.2 & 2.7 & 33.6 & 15.8 & 66.9 & 23.2 & 99.7 \\
\hline USAA Federal Savings Bank & Large bank & 41 & 1 & 32 & 27.6 & .0 & 15.4 & 9.7 & 64.7 & 15.6 & 95.5 \\
\hline Top 25 institutions & $\cdots$ & 2,476 & 1,231 & 865 & 64.6 & 2.0 & 24.3 & 12.8 & 63.7 & 20.5 & 83.4 \\
\hline All institutions & $\cdots$ & 7,404 & 2,102 & 3,124 & 60.6 & 3.2 & 28.0 & 13.5 & 68.1 & 19.9 & 84.8 \\
\hline
\end{tabular}

1 See table 10 , note 1.

2 First-lien mortgages for one- to four-family, owner-occupied, site-built homes.

3 Share of conventional loans that are higher priced.

4 See table 2, note 3.

5 See table 2, note 4

6 See table 2, note 1. "Minority borrower" refers to nonwhite (excluding joint or missing) or Hispanic white applicants.

7 See table 10 , note 6 .

... Not applicable.

Source: FFIEC HMDA data; bank asset data drawn from Federal Deposit Insurance Corporation Reports of Condition and Income (https://www .fdic.gov).

(continued on next page)

were LMI, while at other institutions, fewer than 20 percent of borrowers were in that category. ${ }^{42}$ Although it is difficult to know precisely why such variation exists, these differences could reflect different business strategies, different customer demands in the markets and geographic regions the institutions serve, or some combination of these two broad factors.

\footnotetext{
${ }^{42}$ Note that for lenders with a significant nonconventional share of refinance loans (for example, Freedom Mortgage Corporation), borrower income may not be reported for most loans, thus pushing down the LMI share of borrowers.
} 
Table 11. Top 25 respondents in terms of total originations, 2015-continued

Percent except as noted

\begin{tabular}{|c|c|c|c|c|c|c|c|c|c|}
\hline \multirow[b]{2}{*}{ Respondent } & \multirow[b]{2}{*}{$\begin{array}{l}\text { Institution } \\
\text { type }^{1}\end{array}$} & \multicolumn{8}{|c|}{ Refinance loans ${ }^{2}$} \\
\hline & & $\begin{array}{l}\text { Number } \\
\text { (thous- } \\
\text { ands) }\end{array}$ & $\begin{array}{l}\text { Con- } \\
\text { ven- } \\
\text { tional }\end{array}$ & $\begin{array}{l}\text { Higher } \\
\text { priced }^{3}\end{array}$ & $\begin{array}{l}\text { LMI } \\
\text { bor- } \\
\text { rower }^{4}\end{array}$ & $\begin{array}{l}\text { LMI } \\
\text { neigh- } \\
\text { bor- } \\
\text { hood }^{5}\end{array}$ & $\begin{array}{l}\text { Non- } \\
\text { Hispanic } \\
\text { white }^{6}\end{array}$ & $\begin{array}{l}\text { Minority b } \\
\text { orrower }^{6}\end{array}$ & Sold ${ }^{7}$ \\
\hline Wells Fargo Bank, NA & Large bank & 186 & 85.3 & .6 & 18.1 & 11.7 & 66.9 & 18.7 & 88.3 \\
\hline Quicken Loans, Inc. & Ind. mort. co. & 279 & 67.0 & .2 & 23.4 & 12.7 & 53.6 & 11.5 & 100.0 \\
\hline Bank of America, NA & Large bank & 94 & 97.2 & .1 & 24.3 & 12.9 & 64.1 & 24.3 & 79.0 \\
\hline JPMorgan Chase Bank, NA & Large bank & 88 & 97.6 & 1.2 & 19.4 & 9.6 & 68.3 & 18.4 & 51.4 \\
\hline U.S. Bank, NA & Large bank & 57 & 94.3 & 3.4 & 23.1 & 12.7 & 63.6 & 11.3 & 55.4 \\
\hline Freedom Mortgage Corp. & Ind. mort. co. & 77 & 9.0 & .0 & 3.8 & 15.4 & 61.6 & 23.4 & 100.0 \\
\hline IoanDepot.com & Ind. mort. co. & 62 & 67.0 & .5 & 17.1 & 12.1 & 64.5 & 18.6 & 100.0 \\
\hline Flagstar Bank, FSB & Large bank & 41 & 78.5 & .4 & 14.5 & 11.0 & 63.7 & 25.7 & 91.5 \\
\hline Caliber Home Loans, Inc. & Ind. mort. co. & 18 & 75.4 & .4 & 16.9 & 11.8 & 64.9 & 18.3 & 96.8 \\
\hline PNC Bank, NA & Large bank & 30 & 86.5 & .1 & 28.9 & 13.5 & 68.4 & 11.5 & 62.3 \\
\hline Citibank, NA & Large bank & 35 & 96.3 & .0 & 22.1 & 12.3 & 58.9 & 19.7 & 81.4 \\
\hline Navy Federal Credit Union & Credit union & 15 & 48.0 & 1.7 & 14.6 & 11.3 & 53.7 & 23.9 & 50.4 \\
\hline Nationstar Mortgage & Ind. mort. co. & 49 & 88.2 & 2.1 & 11.7 & 17.4 & 62.6 & 25.7 & 99.9 \\
\hline Stearns Lending, Inc. & Ind. mort. co. & 24 & 66.0 & .1 & 18.4 & 14.2 & 64.6 & 23.6 & 100.0 \\
\hline $\begin{array}{l}\text { PrimeLending, a } \\
\text { PlainsCapital Company }\end{array}$ & $\begin{array}{l}\text { Affiliated } \\
\text { mort. co. }\end{array}$ & 11 & 84.7 & 1.0 & 18.1 & 10.9 & 74.7 & 14.7 & 100.0 \\
\hline Guild Mortgage Co. & Ind. mort. co. & 12 & 63.7 & .3 & 17.3 & 15.6 & 65.0 & 18.5 & 99.9 \\
\hline Ditech Financial LLC & Ind. mort. co. & 37 & 96.5 & .1 & 37.6 & 16.5 & 66.6 & 19.3 & 99.9 \\
\hline Shore Mortgage & Ind. mort. co. & 23 & 94.3 & .3 & 17.1 & 11.3 & 62.5 & 27.5 & 100.0 \\
\hline Guaranteed Rate, Inc. & Ind. mort. co. & 17 & 91.4 & .2 & 13.1 & 9.6 & 76.7 & 12.7 & 100.0 \\
\hline $\begin{array}{l}\text { Fairway Independent } \\
\text { Mortgage Corp. }\end{array}$ & Ind. mort. co. & 8 & 76.5 & .4 & 18.6 & 11.3 & 79.6 & 11.1 & 99.8 \\
\hline Branch Banking and Trust $\mathrm{Co}$. & Large bank & 13 & 92.3 & .5 & 23.1 & 11.0 & 71.8 & 8.6 & 73.5 \\
\hline Regions Bank & Large bank & 16 & 95.7 & .6 & 26.6 & 13.4 & 79.4 & 15.6 & 23.9 \\
\hline SunTrust Mortgage, Inc. & $\begin{array}{l}\text { Affiliated } \\
\text { mort. co. }\end{array}$ & 22 & 89.9 & .1 & 22.2 & 10.5 & 65.8 & 15.0 & 97.3 \\
\hline Academy Mortgage Corp. & Ind. mort. co. & 7 & 74.3 & .8 & 20.8 & 12.0 & 77.6 & 14.8 & 99.9 \\
\hline USAA Federal Savings Bank & Large bank & 7 & 32.8 & .0 & 9.1 & 9.5 & 60.8 & 17.0 & 86.2 \\
\hline Top 25 institutions & $\ldots$ & 1,229 & 77.1 & 6 & 19.8 & 12.6 & 62.9 & 17.7 & 87.2 \\
\hline All institutions & $\cdots$ & 2,810 & 76.6 & 1.6 & 19.0 & 12.3 & 67.2 & 17.1 & 82.7 \\
\hline
\end{tabular}




\section{Appendix A: Requirements of Regulation C}

Regulation C requires lenders to report the following information on home-purchase and home-improvement loans and on refinancings:

\section{For each application or loan}

- application date and the date an action was taken on the application

- action taken on the application

- approved and originated

- approved but not accepted by the applicant

- denied (with the reasons for denial - voluntary for some lenders)

- withdrawn by the applicant

- file closed for incompleteness

- preapproval program status (for home-purchase loans only)

- preapproval request denied by financial institution

- preapproval request approved but not accepted by individual

- loan amount

- loan type

- conventional

— insured by the Federal Housing Administration

- guaranteed by the Department of Veterans Affairs

— backed by the Farm Service Agency or Rural Housing Service

- lien status

- first lien

- junior lien

— unsecured

- loan purpose

- home purchase

- refinance

- home improvement

- type of purchaser (if the lender subsequently sold the loan during the year)

- Fannie Mae

- Ginnie Mae

- Freddie Mac

- Farmer Mac

- private securitization

- commercial bank, savings bank, or savings association

- life insurance company, credit union, mortgage bank, or finance company

- affiliate institution

— other type of purchaser

\section{For each applicant or co-applicant}

- race

- ethnicity

- $\operatorname{sex}$

- income relied on in credit decision 


\section{For each property}

- location, by state, county, metropolitan statistical area, and census tract

- type of structure

— one- to four-family dwelling

- manufactured home

- multifamily property (dwelling with five or more units)

- occupancy status (owner occupied, non-owner occupied, or not applicable)

\section{For loans subject to price reporting}

- spread above comparable Treasury security for applications taken prior to October 1, 2009

- spread above average prime offer rate for applications taken on or after October 1, 2009

\section{For loans subject to the Home Ownership and Equity Protection Act}

- indicator of whether loan is subject to the Home Ownership and Equity Protection Act 